\title{
Carbon Nanomaterials in Agriculture: A Critical Review
}

\author{
Arnab Mukherjee ${ }^{1}$, Sanghamitra Majumdar', Alia D. Servin ${ }^{1}$, Luca Pagano ${ }^{1,2,3}$, \\ Om Parkash Dhankher ${ }^{3}$ and Jason C. White ${ }^{1 *}$
}

${ }^{1}$ Department of Analytical Chemistry, Connecticut Agricultural Experiment Station, New Haven, CT, USA, ${ }^{2}$ Department of Life Sciences, University of Parma, Parma, Italy, ${ }^{3}$ Stockbridge School of Agriculture, University of Massachusetts Amherst, Amherst, MA, USA

\section{OPEN ACCESS}

Edited by:

Karina Vera Rosa Schafer,

Rutgers, The State University of New Jersey, USA

Reviewed by: Timothy S. Fisher,

Purdue University, USA

Arturo A. Keller,

University of California, Santa Barbara, USA

*Correspondence: Jason C. White jason.white@ct.gov

Specialty section: This article was submitted to Functional Plant Ecology, a section of the journal

Frontiers in Plant Science

Received: 09 September 2015 Accepted: 01 February 2016 Published: 22 February 2016

Citation:

Mukherjee A, Majumdar S, Servin AD, Pagano L, Dhankher OP and White JC (2016) Carbon Nanomaterials in Agriculture: A Critical Review. Front. Plant Sci. 7:172. doi: 10.3389/fpls.2016.00172
There has been great interest in the use of carbon nano-materials (CNMs) in agriculture. However, the existing literature reveals mixed effects from CNM exposure on plants, ranging from enhanced crop yield to acute cytotoxicity and genetic alteration. These seemingly inconsistent research-outcomes, taken with the current technological limitations for in situ CNM detection, present significant hurdles to the wide scale use of CNMs in agriculture. The objective of this review is to evaluate the current literature, including studies with both positive and negative effects of different CNMs (e.g., carbon nano-tubes, fullerenes, carbon nanoparticles, and carbon nano-horns, among others) on terrestrial plants and associated soil-dwelling microbes. The effects of CNMs on the uptake of various co-contaminants will also be discussed. Last, we highlight critical knowledge gaps, including the need for more soil-based investigations under environmentally relevant conditions. In addition, efforts need to be focused on better understanding of the underlying mechanism of CNM-plant interactions.

Keywords: carbon nano-materials, toxicity, soil-microbes, co-contaminants, CNM-plant interactions

\section{INTRODUCTION}

Carbon nanomaterials (CNMs) are a class of engineered nanomaterials (ENMs) seeing increased applications due to their exceptional optical, electrical, mechanical, and thermal properties (Hurt et al., 2006; Bennett et al., 2013; Srivastava et al., 2015). The synthesis of CNMs has evolved significantly over the last two decades. The discovery of Buckminster $\left(\mathrm{C}_{60}\right)$ fullerenes in 1985 was followed by carbon nanotubes in 1991, and the graphene-family in 2004, which continues to dominate most applications (Bergmann and Machado, 2015; Hong et al., 2015).

Carbon assumes thermodynamically favorable configurations from $\mathrm{sp}^{3}$ to $\mathrm{sp}^{2}$, depending on the heat of formation and pressure conditions, to produce structures such as nano-diamonds and graphene sheets (Mauter and Elimelech, 2008). CNMs combine the quantum effects at the nanoscale, the stability of resonance structures, and the tunable distinctive physico-chemical properties due $\mathrm{sp}^{3}$ character of C-C bonds (Mauter and Elimelech, 2008). The CNM family includes fullerenes, nano-onions, nano-cones, nano-horns, carbon dots, carbon nanotubes (CNTs), nano-beads, nano-fibers, nano-diamonds, and graphene (Sharon and Sharon, 2010; Cha et al., 2013; Baptista et al., 2015). They exhibit huge diversity in their structures as well as size, which is not exclusively confined to nanoscale $(<100 \mathrm{~nm})$ in all dimensions. For example, graphene is a two dimensional -one atom thick sheet of $\mathrm{sp}^{2}$-C-atoms in a hexagonal honeycomb crystal lattice, with $\mathrm{sp}^{3}$-C-atoms at the defect sites. It is regarded as the "building block" for other graphenic/graphitic nanoallotropes (Georgakilas et al., 2015). Fullerenes are hollow spheres with a 
hexagonal network of carbon atoms and $\leq 1 \mathrm{~nm}$ in diameter (Chichiriccò and Poma, 2015). Concentric multi-layered fullerenes called nano-onions are also seeing increased use in biomedical and electrochemical applications (Bartelmess and Giordani, 2014). Although they are limited in actual commercialization, Benn et al. (2011) detected pristine $\mathrm{C}_{60}$ fullerenes in different commercial cosmetics, at concentrations ranging from 0.04 to $1.1 \mu \mathrm{g} / \mathrm{g}$. CNTs are cylindrical structures with open or closed ends and can further be categorized into single-wall (SWCNTs) and multi-wall nanotubes (MWCNTs) depending on the number of concentric layers of rolled graphene sheets (Yang et al., 2010; De Volder et al., 2013). The outer diameter of CNTs is typically 0.8 to $2 \mathrm{~nm}$ for SWCNTs, and 5-20 nm for MWCNTs (De Volder et al., 2013). The lengths range from $100 \mathrm{~nm}$ to several centimeters, depending on the desired application (De Volder et al., 2013). Owing to their tunable physical properties with respect to graphene layers, functionalization, and chirality, CNTs and associated polymer composites are the most produced CNMs, with applications including in electronics, optics, nanomedicine, and biosensors (Mauter and Elimelech, 2008; Yang et al., 2010; De Volder et al., 2013; Keller et al., 2013). They are also utilized for environmental applications such as solar cells, renewable energy production with higher efficiency, remediation purposes, detection/sensors for pollutants, and for contaminant degradation (Mauter and Elimelech, 2008; Baptista et al., 2015; Rasool and Lee, 2015). Additionally, hollow CNMs such as fullerenes, CNTs, and nano-horns are capable of serving as carrier molecules for metals, atoms or active ingredients in sensors and biomedical applications (Georgakilas et al., 2015).

Recent CNM exposure studies have demonstrated beneficial and stimulatory effects on plants in vitro or in culture conditions. These findings have increased interest in potential applications in agriculture and food production (Serag et al., 2015), although the findings are somewhat inconsistent. MWCNTs have been reported to be internalized in plant roots (Lin et al., 2009). SWCNTs have also been proven to efficiently cross the cell wall and membranes of tobacco cells upon in vitro exposure, with subsequent transport to specific cellular organelles; this could be taken as evidence for potential use as "nanotransporters" (Samaj et al., 2004; Liu et al., 2009). Additionally, the suppression of organic contaminant uptake by plants has been reported in the presence of select CNMs (Petersen et al., 2009; De La TorreRoche et al., 2013).

In spite of the wide scope of CNMs application in agriculture, there are several limiting factors impeding their extensive use. First, although in artificial plant cultures select CNMs have rendered toxicity at physiological, cellular, and genetic levels (Ghosh et al., 2015), there are very limited number of studies evaluating the chronic phytotoxicity of CNMs under environmentally relevant conditions. Notably, assessment of CNM toxicity in soil is confounded by a large number of factors, including low solubility, reactivity with soil organic matter, and large background from the residual $\mathrm{C}$ in soil; all factors limit detection and complicate a mechanistic understanding of cellular interactions. Second, there is little information on the nutritional effects and potential genetic modifications/damages in CNMexposed plants, including transgenerational impacts (Lin et al., 2009; Husen and Siddiqi, 2014; Ghosh et al., 2015). Third, stability of the CNMs in a complex media and residual leaching of attached metals or contaminants from CNMs (Bennett et al., 2013) is poorly understood. Finally, CNM transfer from soil to plants and subsequently to higher herbivore and carnivore trophic levels is completely unknown. As such, direct agricultural applications are still in experimental phase given this limited knowledge of CNM fate and effects on agroecosystems.

Interestingly, in spite of the above listed concerns, CNTs are among the 10 most produced ENMs (Keller et al., 2013), and along with graphene, CNTs are considered viable for expanded use in commercial applications (De Volder et al., 2013). With increasing scope of production and application, their release into the environment with subsequent human exposure is inevitable. Petersen et al. (2011) provided a comprehensive review on the environmental exposure, fate, and risks associated with the use of CNTs. A thorough understanding of the mechanistic interactions of CNMs with plants and associated microbial communities is necessary to evaluate the risk associated with widespread use in agriculture. The aim of the current review is to provide a thorough evaluation of the existing literature on CNM fate in soil, including effects on plants and associated soil microorganisms. We will also critically assess the limitations in the current literature and highlight topics worthy of future investigation.

\section{Fate of Carbon Nanomaterials in the Environment}

In spite of growing interest and research, regulatory agencies have become concerned that the potential negative impacts of these materials in the environment may outweigh their benefits. Compared to application-based research and development, studies on the ecotoxicity of CNMs are quite limited and involve a narrow range of test species and materials, growth media, and analytical techniques. Owing to their unique and reactive properties, some speculate that CNMs may have the potential to not only impact individual species but also to disrupt ecological dynamics (Jackson et al., 2013). Accurate delineation of the sources, pathways and sinks is needed for a complete CNM risk assessment. In recent years, the global production of CNTs were reported to range from 55 to 3,300 tons and of fullerenes from 0.6 to 1620 tons (Sun et al., 2014). These materials can enter the environment via emission from manufacturing processes (Bello et al., 2009), either accidentally or/and as waste discharge in air/water/landfills.

Human exposure to CNMs may occur through occupational settings or through indirect exposure from various environmental matrices such as air, water, and soils/sediments. Nowack et al. (2013) suggested that the predominant release pathway is during initial synthesis and handling of ENMs, which will result in occupational exposure and perhaps large-scale environmental exposure if an accidental release occurs. Ogura et al. (2013) investigated the release characteristics of SWCNTs in a pilot scale-plant, using on-site aerosol measurements and dustiness tests with vortex shaking and transferring containers. The authors reported that the elemental carbon content increased 
during the synthesis, which also includes the particles from the combustion process. But the concentration of elemental carbon was within the suggested occupational exposure limits proposed by US NIOSH $\left(7 \mu \mathrm{g} / \mathrm{m}^{3}\right)$. Interestingly, dustiness testing suggested low release characteristics and low drop impact of SWCNTs owing to their low bulk densities; mostly micron-sized CNT clusters were observed by scanning electron microscopy (SEM). This might suggest that SWCNTs have lower chances of accumulating in soil and sediments. The major fraction of fullerene and CNTs produced are as polymer composites, thus making them a major source for release of CNMs. Petersen et al. (2011) discussed various release pathways of CNT-incorporated polymer nanocomposites, during their usage and disposal in a comprehensive review. The authors reviewed various natural conditions including radiation, UV light, moisture, temperature and microbes leading to degradation of polymer matrix holding the CNTs, resulting in particle release. Also, activities during composite such as mechanical abrasion and incineration can lead to release of the nanomaterials in an uncontrolled manner. However, the literature is largely silent on the release scenarios of many CNMs, including fullerenes, graphene, etc. and their fate in various environmental matrices.

Importantly, CNM stability and transport will not only depend on native material properties but also on the characteristics of any conjugated composites and on the surrounding conditions (Nowack et al., 2013). In the past few years, mass flow modeling studies have been implemented to assess the flow of various ENMs in the environment, starting from the global/ regional production to release via usage and waste disposal, and finally, compartmentalization in different ecological matrices (Gottschalk et al., 2009; Keller et al., 2013; Mueller et al., 2013; Sun et al., 2014). Employing Monte Carlo simulations based on total usage in a defined region (EU and Switzerland), Sun et al. (2014) suggested that most of the CNMs flow from the production to recycling and waste incineration plants, and finally to elimination. The predicted annual accumulation of 0.4 and $0.8 \mu \mathrm{g} / \mathrm{kg}$ of fullerenes and CNTs, respectively, was reported in the sediments accepting the ENM contaminated surface waters (Sun et al., 2014). Due to lack of specific regulations for ENM disposal, CNMs composites are often incinerated, and the formation of aerosols or air borne particles containing the CNTs is possible (Petersen et al., 2011; Nowack et al., 2013). Using mass models, Mueller et al. (2013) proposed that $94 \%$ of the CNTs are completely mineralized during the incineration process of waste handling, and that the residual amount discharged to the air and water (waste water treatment plant) is insignificant $(<0.0001$ and $0.0005 \%$, respectively); $5 \%$ is direct disposal into the landfills. Thus, the primary exposure to CNMs could be considered via usage and disposal, rather than during manufacturing processes.

According to life cycle release modeling studies, soils/sediments and landfills are the sink for an estimated $80 \%$ of CNMs released into the environment (Keller et al., 2013). Due to their hydrophobicity, CNMs are often readily soluble in organic solvents. However, soil pore water and various other soil components or co-contaminants may affect CNM fate and stability (Bennett et al., 2013). Surfactants and natural organic matter (NOM) have been reported to stabilize CNTs in the aqueous phase, thereby enhancing material mobility in soil systems (Lecoanet et al., 2004; Hyung et al., 2007; Hyung and Kim, 2008; Bennett et al., 2013). Soil properties such as $\mathrm{pH}$, clay and organic carbon content, texture, and mineralogy could affect CNM mobility in the environment (Avanasi et al., 2014). The transport of the CNMs within environmental compartments is dependent on particle colloidal stability as well as their in situ transformation. The sorption properties and chemical transformation of CNMs may dictate mobility in soils and sediments, and hence their bioavailability. Zhang et al. (2012) evaluated the association between an aqueous dispersion of MWCNT and different soil minerals (kaolinite, smectite, or shale) under varying sodium levels. Using ${ }^{14} \mathrm{C}$-labeling studies, the authors showed that the removal of MWCNTs from the aqueous phase was directly proportional to the ionic strength and hydrophobicity of the minerals. This shows that the type of soil is a critical factor controlling CNM residence in the pore water that is readily available to both, plants and the soil microbial community. In a related study with $\mathrm{C}_{60}$-fullerenes, Avanasi et al. (2014) suggested that CNMs are resistant to mineralization and would persist in soil at least for 1-2 years.

At this point, general conclusions on CNMs fate in the soil environment are difficult to draw as the process is dependent on multiple factors related soil physicochemical characteristics and composition, as well as CNM properties and the identity/susceptibility of potential receptors. Varying physicochemical properties of CNMs produced for specific applications make risk assessment of these particles rather uncertain. Thus, further research on CNM agglomeration, sorption in varying solids and interaction with root exudates and biological fluids is needed before drawing conclusions over CNM fate in the environment. Accurate assessment of fate and associated risks of the CNMs will not only help in regulating the current use of these materials, but also aid in the manufacture of safer-by-design nanomaterials.

\section{EFFECTS OF CNMS IN PLANTS}

A number of different carbon-based NMs (CNMs: fullerenes, carbon NPs, fullerol, and SWCNT/MWCNT, among others) have recently gained interest due to their possible applications in regulating plant growth (Khot et al., 2012). Importantly, the literature shows both positive and negative effects on terrestrial plant species, depending upon CNM type and concentration, growth conditions, and plant species. In this section, we present these effects separately.

\section{Positive Effects}

Although most studies have focused on toxicological/ physiological endpoints, several early studies did attempt to evaluate CNM accumulation in plants (Table 1). In a hydroponic study, Lin and Xing (2007) found significant increase in ryegrass (Lolium perenne) root length $(\sim 17 \%)$ upon exposure to $2000 \mathrm{mg} / \mathrm{L}$ MWCNT (ryegrass) as compared to 
untreated controls. Canas et al. (2008) evaluated the toxicity of uncoated and coated SWCNTs [poly-3-aminobenzenesulfonic acid (PABS); PABS: CNTs $=65: 35(\mathrm{w} / \mathrm{w})]$ to six crop species; cucumber (Cucumis sativus), carrot (Daucus carota), onion (Allium cepa), tomato (Lycopersicon esculentum), cabbage (Brassica oleracea), and lettuce (Lactuca sativa). The plants were exposed hydroponically to coated $(0,160,900$, and $5,000 \mathrm{mg} / \mathrm{L})$ and uncoated-CNTs $(0,104,315$, and $1750 \mathrm{mg} / \mathrm{L})$ for 24 and 48 h. Upon exposure, uncoated-CNTs increased root length in onion and cucumber as compared to the coated-CNTs. Although, variability was high $(0-30 \%$ for uncoated-CNTs and $5-83 \%$ for coated-CNTs), an inverse relationship between exposure time and the extent of root elongation was observed, i.e., 1-day-exposure showed more pronounced effects than 2-day-treatments. Interestingly, microscopic studies revealed no internalization of CNTs into the roots; only surface adsorption was evident. Therefore, authors hypothesized that CNTs might impose indirect effects on plant root systems, such as impeding

TABLE 1 | Positive effects of carbon nano-materials (CNMs) in plant.

\section{Effect}

\begin{tabular}{|c|c|c|}
\hline Reference & CNM & Treatment \\
\hline Samaj et al., 2004 & CNT & - \\
\hline Lin and Xing, 2007 & MWCNT & 2000 mg/L in ryegrass (Lolium perenne) \\
\hline Canas et al., 2008 & $\begin{array}{l}\text { Uncoated and PABS coated } \\
\text { SWCNTs }\end{array}$ & $\begin{array}{l}\text { coated }[0,160,900 \text {, and } 5,000 \mathrm{mg} / \mathrm{L}) \text { and } \\
\text { uncoated-CNTs }(0,104,315 \text {, and } 1750 \mathrm{mg} / \mathrm{L}) \\
\text { for } 24 \text { and } 48 \mathrm{~h} \text {. }\end{array}$ \\
\hline Liu et al., 2009 & SWCNT & - \\
\hline $\begin{array}{l}\text { Wild and Jones, } \\
2009\end{array}$ & MWCNT & - \\
\hline Tripathi et al., 2011 & $\begin{array}{l}\text { Citrate coated water-soluble } \\
\text { CNTs }\end{array}$ & 10-days exposure to $6.0 \mathrm{mg} / \mathrm{mL}$ \\
\hline $\begin{array}{l}\text { Khodakovskaya } \\
\text { et al., } 2011\end{array}$ & SWCNT and MWCNT & $50 \mathrm{mg} / \mathrm{L}$ \\
\hline Mondal et al., 2011 & $\begin{array}{l}\text { Pristine (diameter } \sim 30 \mathrm{~nm} \text { ) and } \\
\text { oxidized-MWCNT }\end{array}$ & In mustard (Brassica juncea) at 2.3-46.0 $\mu \mathrm{g} / \mathrm{L}$ \\
\hline Wang et al., 2012 & o-MWCNT & 40,80, and $160 \mathrm{mg} / \mathrm{L}$ for 3 and 7 days \\
\hline Sonkar et al., 2012 & $\begin{array}{l}\text { Water-soluble carbon } \\
\text { nano-onions }\end{array}$ & $\begin{array}{l}5 \text { and } 10-\text { days hydroponic germination at } 10 \text {, } \\
20 \text {, and } 30 \mathrm{mg} / \mathrm{L}\end{array}$ \\
\hline Lahiani et al., 2013 & MWCNT & $10-11 \mathrm{~d}$ at 50,100 , and $200 \mathrm{mg} / \mathrm{L}$ \\
\hline
\end{tabular}

Uptake through endocytosis.

Increased root length ( $17 \%)$.

Uncoated-CNTs increased root length in onion and cucumber as compared to the coated-CNTs.

SWNTs as potential cargo for several molecules into different plant cell organelles.

CNTs were adsorbed onto the root surface but also did appear 'pierce' the root epidermal cells and accumulate within the tissue.

Visualize internalization of the coated ws-CNTs by SEM and TEM.

enhanced the total fresh biomass

Enhanced germination, increased root and shoot growth.

Increase in root length of wheat seedlings

Growth enhancement.

$50 \%$ (in barley and soybean) and 90\% (in corn) increase in germination. In soybean, the root length increased up to $26 \%$. In corn, shoot and leaf length were enlarged by $40 \%$ and more than threefold, respectively. Internalization was visualized by both Raman Spectroscopy and TEM.

$60 \mathrm{mg} / \mathrm{L}$ treatment; increased plant fresh biomass (43\%) and higher nutrient uptake ( $2 x$ calcium and 1.6x iron)

\begin{tabular}{|c|c|c|}
\hline Kole et al., 2013 & Fullerols $\mathrm{C}_{60}(\mathrm{OH})_{20}$ & $0.943,4.72,9.43,10.88$, and $47.2 \mathrm{nM}$ fullerol \\
\hline $\begin{array}{l}\text { Tripathi and Sarkar, } \\
2014\end{array}$ & Cabon nano-dots & $\begin{array}{l}10 \text { days of exposure to } 150 \mathrm{mg} / \mathrm{L} \text { water soluble } \\
\text { carbon nano-dots }\end{array}$ \\
\hline Saxena et al., 2014 & Water-soluble CNPs & $10-150 \mathrm{mg} / \mathrm{L}$ ws-CNPs in soil up to 20 days \\
\hline
\end{tabular}

Lahiani et al., 2015 Carbon nano-horns (CNHs)

25, 50 and $100 \mathrm{mg} / \mathrm{ml}$ for 10-20 days barley, corn, rice, soybean, switchgrass, tomato) and tobacco cell culture
Increased plant biomass and phytomedicine content in bitter melon.

Enhanced root growth (10x) of wheat.

Optimum growth was observed at $50 \mathrm{mg} / \mathrm{L}$ treatment where root and shoot lengths were increased up to 3-times.

Growth of tobacco cells was increased $78 \%$. Uptake confirmed by TEM.

\section{Co-contaminants}

Ma and Wang,

2010

De La Torre-Roche

et al., 2012

Hamdi et al., 2015
Fullerene + Trichloroethylene (TCE)

Fullerene + DDE

CNT + chlordane components;

$\mathrm{CNT}+\mathrm{DDE}$
2-15 mg/L fullerene in by eastern cottonwood

$40 \mathrm{mg} \mathrm{C} 60+100 \mathrm{ng} / \mathrm{mL}$ DDE for 3 weeks

$1000 \mathrm{mg} / \mathrm{L}$ for a 19-day in lettuce
TCE uptake increase with increase in fullerene concentration.

Zucchini and soybean, a 29\% increase and a 48\% decrease in $p, p^{\prime}$-DDE uptake were observed upon fullerene exposure

Non-functionalized CNT was more effective at reducing the organochlorine accumulation by plant roots (88\%) and shoots (78\%). 
microbial-root interactions, causing toxicity to microbes or altering crucial biochemical processes such as nutrient acquisition. Wild and Jones (2009) noted that upon exposure to wheat, CNTs were adsorbed onto the root surface but also did appear 'pierce' the root epidermal cells and accumulate within the tissue.

Conversely, Tripathi et al. (2011) investigated the impact of citrate coated water-soluble CNTs (ws-CNT) in gram (Cicer arietinum) after a 10-days exposure to $6.0 \mathrm{mg} / \mathrm{mL}$ and were able to visualize internalization of the CNTs by electron microscopy. The authors hypothesized that once present inside the vascular tissue, ws-CNTs formed an 'aligned network' that increased water uptake efficiency and directly resulted in the observed plant growth enhancement (Tripathi et al., 2011).

There have been several other reports of plant growth enhancement upon CNT exposure. Mondal et al. (2011) studied the effect of pristine (diameter $\sim 30 \mathrm{~nm}$ ) and oxidized-MWCNT (o-MWCNT; diameter $\sim 20 \mathrm{~nm}$ ) on mustard (B. juncea) at exposures of $2.3-46.0 \mu \mathrm{g} / \mathrm{L}$. The authors reported enhanced germination, as well as increased root and shoot growth. At the lowest concentrations, o-MWCNTs yielded higher rates of germination ( $99 \%$ in 22 days) than did the pristine form ( $94 \%$ in 26 days). However, the rate of germination began to decrease at higher MWCNT exposure levels. After 5-10 days of exposure at the lowest concentrations, both root and shoot lengths were increased by $2.5 \mathrm{x}$ and $1.6 \mathrm{x}$, respectively, as compared to untreated controls. Similarly, Khodakovskaya et al. (2011) showed that in Murashige and Skoog (MS) growth medium, $50 \mu \mathrm{g} / \mathrm{mL}$ SWCNT and MWCNT exposure enhanced the total fresh biomass of tomato seeds by 75 and $110 \%$, respectively, as compared to activated carbon and graphene. In a follow up study, the authors (Khodakovskaya et al., 2012) compared the effects of MWCNT and activated carbon exposure on tobacco cells and demonstrated that growth was 55-64\% higher at $5-500 \mu \mathrm{g} / \mathrm{mL}$ MWCNT exposure as compared to untreated controls. Importantly, although activated carbon enhanced cell growth $(16 \%)$ at low concentrations $(5 \mu \mathrm{g} / \mathrm{mL})$, growth was suppressed by $\sim 25 \%$ at the higher exposures $(100-500 \mu \mathrm{g} / \mathrm{mL})$. Further investigations from this group revealed an upregulation of several genes upon CNT exposure; including an aquaporin $(N t P I P 1)$ and two genes, e.g., $C y c B$ and $N t L R X$, involved in water transport, cell wall formation, and cell division (Khodakovskaya et al., 2012). Similarly, Wang et al. (2012) reported $~ 50$ and 32\% increase in root length of wheat seedlings after 3 and 7 days of exposure to $40-160 \mu \mathrm{g} / \mathrm{L}$ o-MWCNT, respectively. Lahiani et al. (2013) reported the effects of MWCNT exposure (10-11 days at 50,100 , and $200 \mu \mathrm{g} / \mathrm{mL}$ ) on the germination and growth of soybean, corn (Zea mays), and barley (Hordeum vulgare) in agar medium. Upon exposure, nearly 50\% (in barley and soybean) and $90 \%$ (in corn) increases in germination rate were observed compared to untreated controls. In soybean, the root length increased up to $26 \%$ and for corn; shoot and leaf length were enlarged by $40 \%$ and more than threefold, respectively. In addition, MWCNTs internalization was visualized by both Raman Spectroscopy and transmission electron microscopy (TEM; Figure 1). Similar results were reported by Tiwari et al. (2013) for corn exposed to 5-60 mg/L MWCNTs for 7 days in agar medium. At the $60 \mathrm{mg} / \mathrm{L}$ exposure, both plant fresh biomass $(43 \%)$ and nutrient uptake (2x calcium and $1.6 \mathrm{x}$ iron) were increased as compared to controls. Although many studies report positive impacts from CNT exposure, we do note that much of the work is focused on short-term studies with high levels of CNT exposure mostly in artificial growth media. The relevance of these findings to actual agricultural conditions remains unknown but the consistency of the findings across plant species upon CNT treatment clearly warrant further investigation.

Germination and growth enhancement is not limited to CNT exposure; additional CNMs have been shown to positively affect plant physiological parameters as well. Tripathi and Sarkar (2014) reported enhanced root growth (10x) of wheat upon 10 days of exposure to $150 \mathrm{mg} / \mathrm{L}$ water soluble carbon nanodots (ws-CNDs) as compared to controls. Similarly, Sonkar et al. (2012) reported growth enhancement in gram plant from treatment with water-soluble carbon nano-onions (wsCNOs) that were derived from the pyrolysis of wood waste. Specifically, during 5 and 10-days hydroponic germination studies, exposuredependent growth enhancement was observed at 10, 20, and $30 \mu \mathrm{g} / \mathrm{mL}$, when compared to untreated controls. In addition to nano-dots and wsCNOs, water-soluble carbon nanoparticle (wsCNP) such as fullerols, a fullerene derivative $\left[\mathrm{C}_{60}(\mathrm{OH})_{20}\right]$, is another candidate for carbon-based plant growth enhancement. Kole et al., 2013 observed that fullerol increased both the biomass and phytomedicinal content of bitter melon (Momordica charantia), which is a source of various compounds used in the treatment of diseases such as AIDS, diabetes, and cancer (Ng et al., 1992; Raman and Lau, 1996; Basch et al., 2003). Specifically, plants treated with $0.943,4.72,9.43,10.88$, and $47.2 \mathrm{nM}$ fullerol exhibited a 54 and $128 \%$ increase in biomass and fruit yield, respectively. In the fruit tissue, fullerol exposure significantly increased the content of cucurbitacin-B (74\%) and lycopene $(82 \%)$, both of which are anticancer compounds, and the antidiabetic molecules Charantin and insulin were increased by 20 and 91\%, respectively (Kole et al., 2013). Saxena et al. (2014) examined the concentration dependent effects of water-soluble CNPs (ws-CNPs) on wheat. The ws-CNPs were isolated from naturally occurring raw CNPs present in biochar. Plants were treated with $10-150 \mathrm{mg} / \mathrm{L}$ ws-CNPs in soil for up to 20 days; results showed optimum growth at $50 \mathrm{mg} / \mathrm{L}$ treatment with root and shoot lengths increased up to three times compared to untreated controls.

Carbon nano-horns (CNHs) have also been reported positively impact the growth of terrestrial plants (Lahiani et al., 2015). CNHs are spherical structures with "disordered singlelayered graphene sheets with a lateral size of up to $10 \mathrm{~nm}$ and an interlayer distance of approximately 4-5 ^” (Xu et al., 2011). Lahiani et al. (2015) exposed tobacco cells to CNHs at 25, 50, and $100 \mu \mathrm{g} / \mathrm{ml}$ for $24 \mathrm{~h}$ and noted a $78 \%$ increase in growth of cultured tobacco cells at $100 \mu \mathrm{g} / \mathrm{ml}$ while no significant effects at $25 \mu \mathrm{g} / \mathrm{ml}$, as compared to controls. Recently, Zhang et al. (2015) treated tomato seeds in cotton-cushioned glass bottles with $40 \mu \mathrm{g} / \mathrm{ml}$ graphene. Upon exposure, the germination rate at 2, 4, and 6 days was increased by 26.6, 43.4, and 13.5\%, respectively, when compared to untreated controls. 
A

a)

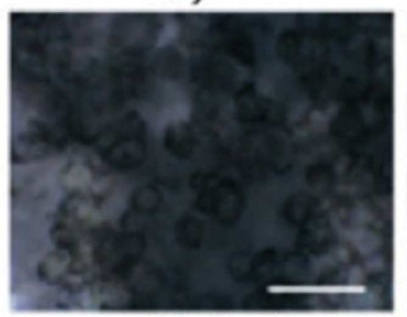

Seed (6 days)

e)

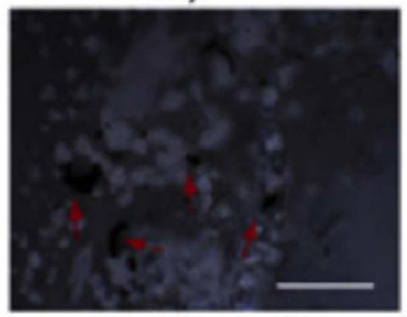

Seed (6 days) b) Controls

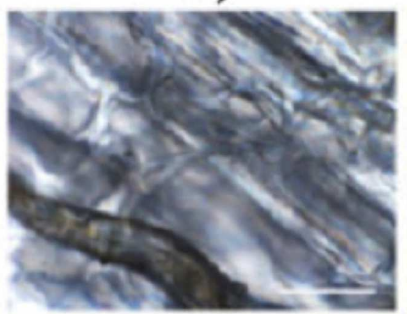

Root ( 6 days) c)

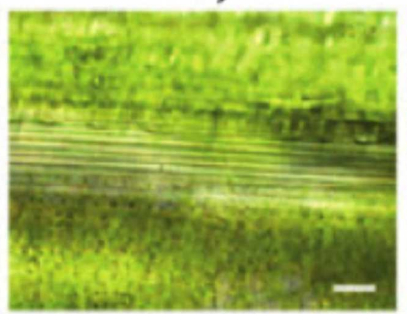

Stem (6 days)

f) With $\mathrm{C}_{70}$-NOM

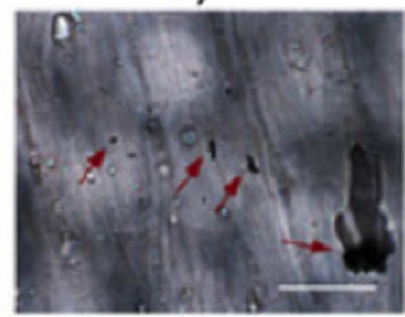

Root (6 days) g)

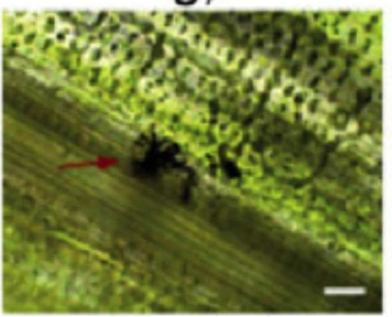

Stem (6 days) d)

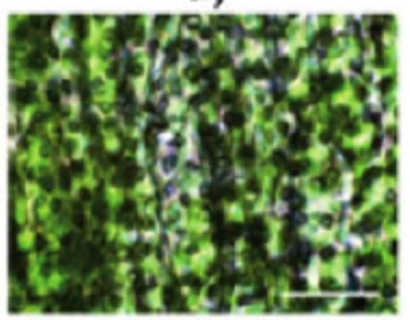

Leaf ( 9 days)

h)

B

a)

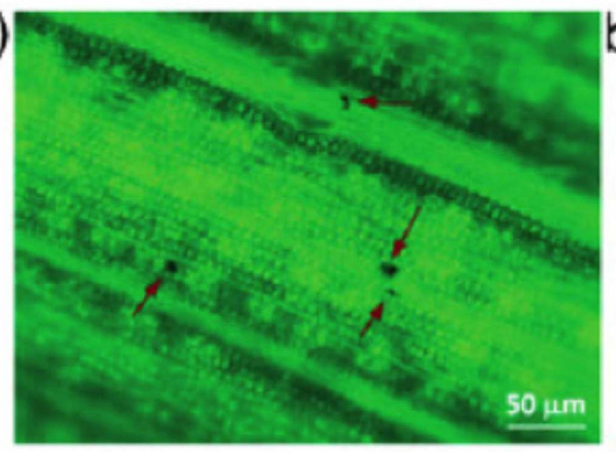

c)

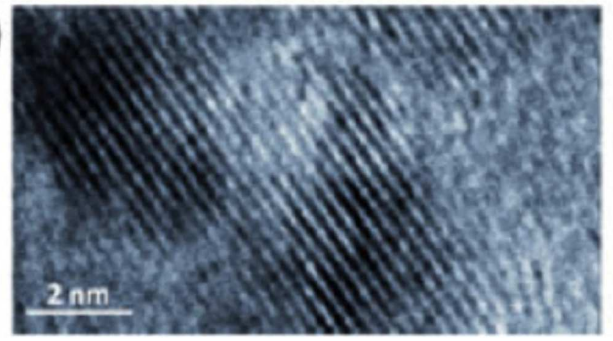

b)

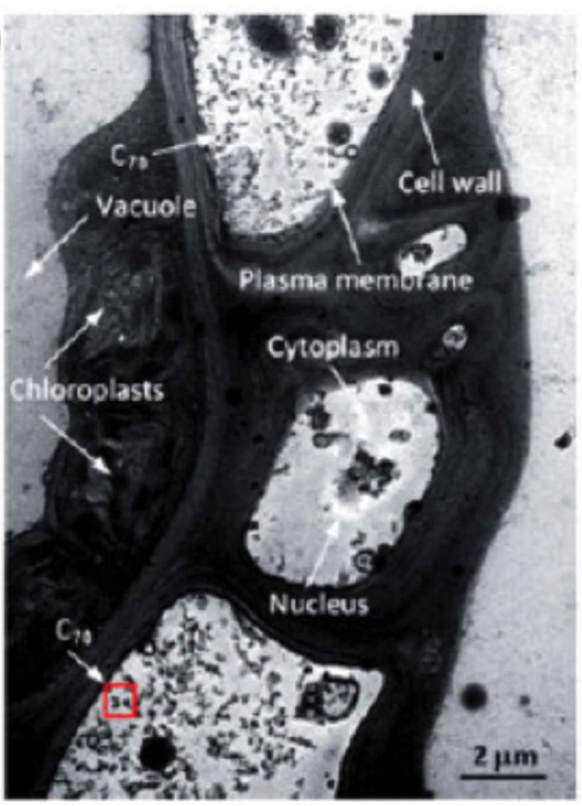

FIGURE 1 | Bright-field images of rice plants showing $\mathbf{C}_{70}$ uptake. (A) Bright field images of root and leaf portions of 1-week-old rice seedlings. Control plants without any $\mathrm{C}_{70}(\mathrm{a}-\mathrm{d})$ and treated plants showing $\mathrm{C}_{70}$ uptake (e and f). Arrows indicate the aggregation of nanoparticles in corresponding $\mathrm{C}_{70}$ treated plant tissues (scale bars are $20 \mu \mathrm{m}$ ). (B) (a) Bright field image of the leaf portion of a second generation rice plant. $\mathrm{C}_{70}$ aggregates were mostly found near the leaf vascular system. (b) TEM image of the leaf cells showing $\mathrm{C}_{70}$ particles $\left(\mathrm{C}_{70}: 20 \mathrm{mg} / \mathrm{L}\right)$. (c) transmission electron microscopy $(T E M)$ image of $\mathrm{C}_{70}$ particles with higher magnification. Reprinted from: Husen and Siddiqi (2014), Copyright @ 2014 Husen and Siddiqi; licensee BioMed Central Ltd. [adopted from Lin et al. (2009), Copyright @ 2009 Wiley-VCH Verlag GmbH \& Co. KGaA, Weinheim].

Apart from direct positive impacts on physiology and growth, select CNMs have been shown to have significant impacts on the fate and transport of several organic co-contaminants. For example, Ma and Wang (2010) reported fullerene-dependent uptake of trichloroethylene (TCE) by eastern cottonwood (Populus deltoides); increases were 26 and $82 \%$ at 2 and 
$15 \mathrm{mg} / \mathrm{L}$ fullerene, respectively. Conversely, De La Torre-Roche et al. (2012) investigated the effects of $\mathrm{C}_{60}$ fullerene on the bioaccumulation of $p, p^{\prime}$-DDE by zucchini, soybean, and tomato in vermiculite and observed differential uptake of $p, p^{\prime}$-DDE across different plant species. In zucchini and soybean, a $29 \%$ increase and a $48 \%$ decrease in $p, p^{\prime}$-DDE uptake were reported upon fullerene exposure, respectively, but no effect was evidenced in tomato. In a follow up soil-based study, the accumulation of weathered chlordane and DDx (DDT + metabolites) decreased by $21-80 \%$ across four crops (zucchini, corn, tomato, and soybean) upon MWCNT co-exposure to 500-5000 mg/kg (De La Torre-Roche et al., 2013; Figure 2). However, $\mathrm{C}_{60}$ co-exposure exhibited mixed effects, ranging from increased chlordane uptake by $34.9 \%$ (soybean/tomato) to complete loss of DDx uptake (tomato/corn). Species dependent uptake of DDE was also observed by Hamdi et al. (2015), where the effects of CNTs surface modification on the uptake of chlordane components (cisand trans-chlordane, trans-non-achlor) and $p, p^{\prime}$-DDE by lettuce was evaluated. After exposure to $1000 \mathrm{mg} / \mathrm{L}$ for 19 days, nonfunctionalized CNT reduced organochlorine content in plant roots and shoots by 88 and 78\%, respectively, but reductions were significantly higher with amino-functionalized CNT (root: 57\% and shoot: $23 \%$ ).

From the above discussion, it is clear that CNMs have potential to enhance plant growth, nutrient uptake, seed germination, and fruit quality. Among the CNMs, CNTs are the most extensively studied and have shown promising positive effects, with low to moderately high doses of CNTs improving overall plant growth. CNTs and fullerenes were also found to have the secondary positive effect of reducing the accumulation of pesticides by select plant species. However, across all studies the beneficial responses are largely dependent on plant species, nature of the growth medium, CNM type/concentration, and growth conditions.

\section{Negative Effects}

A review of the literature reveals a number of reports of showing adverse effects on plants from exposure to a range of CNMs (Table 2). Similar to the positive effects, toxicity was found to be largely dependent on CNM concentrations, growth/exposure conditions, and plant species. However, a general lack of soil based studies confound efforts to extrapolate these findings to field conditions. Results from some of the representative studies are discussed below.

Stampoulis et al. (2009) investigated the effect of MWCNT exposure under hydroponic conditions on zucchini. Upon 15day exposure to $1000 \mathrm{mg} / \mathrm{L}$, a $60 \%$ reduction in biomass reduction was observed when compared to control and bulk carbon. A separate hydroponic study by Mondal et al. (2011) revealed dose dependent toxicity of MWCNTs in mustard, where oxidized-MWCNT exerted more negative effects than pristine MWCNTs. At 'high' exposure concentration, both pristine (46 mg/L) and oxidized-MWCNT (6.9 mg/L) caused toxicity, reducing germination by 4.4 and $7.6 \%$ and dry biomass by 1.6 and 2.2 -fold, respectively, as compared to the lowest concentration. Begum et al. (2011) investigated the speciesdependent toxicity of wter-soluble graphene (GO; 'graphene

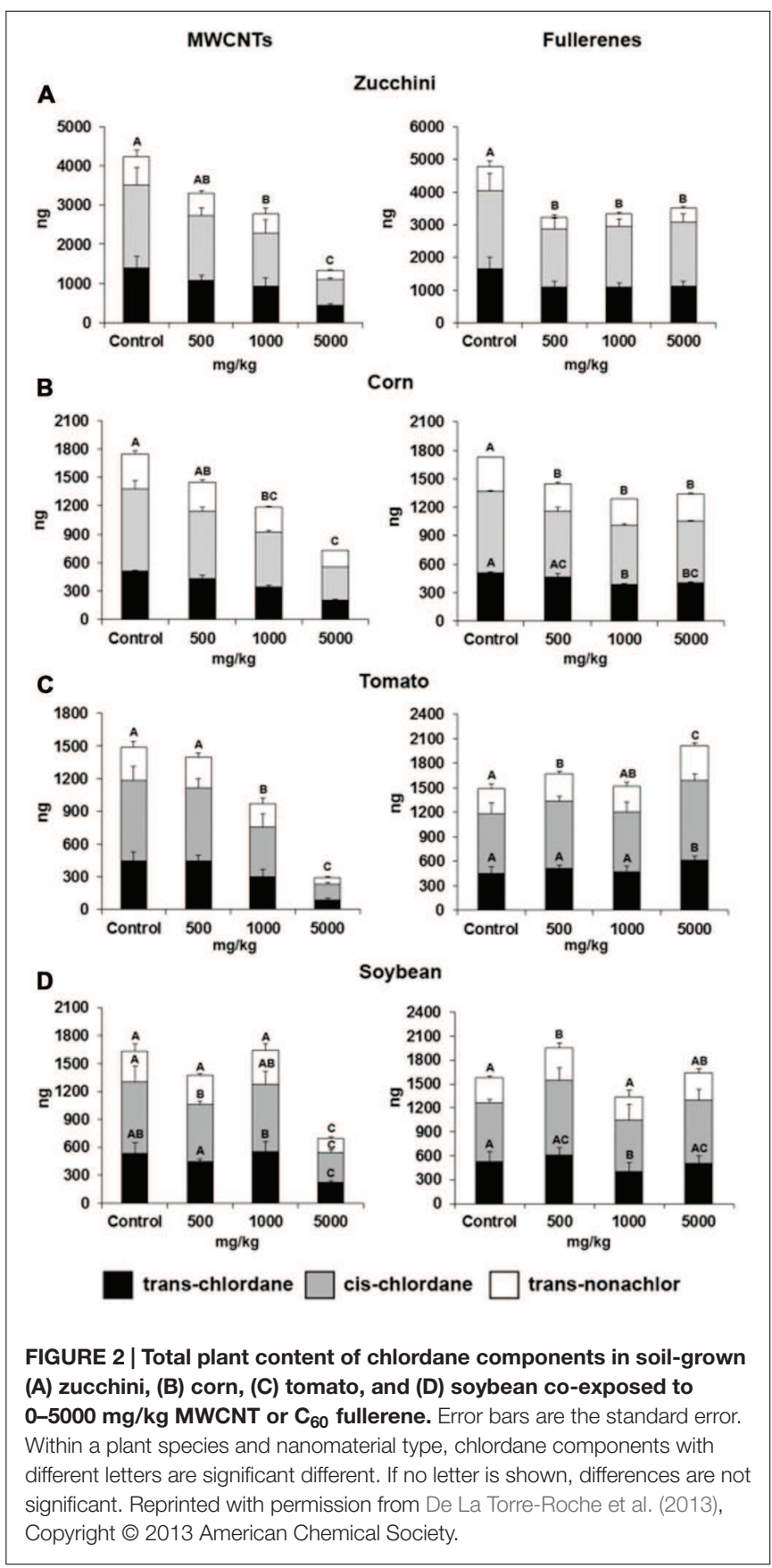

oxide (GO) with sodium ions as the counter-ions') in lettuce, cabbage, red spinach, and tomato during a 20-days exposure period. At the highest concentration $(2000 \mathrm{mg} / \mathrm{L})$, graphene significantly reduced plant growth (up to 78\%), biomass (up to $88 \%$ ), reduced the number and size of leaves (up to 53 and $91 \%$, respectively), and increased reactive oxygen species (ROS) production and necrotic symptoms in all plants except lettuce. In an in vitro study, Arabidopsis thaliana (Columbia ecotype) T87 cells grown in Jouanneau and Péaud-Lenoel (JPL) media were exposed to $0-80 \mathrm{mg} / \mathrm{L}$ graphene (Begum and Fugetsu, 2013). Significant increase in fragmented nuclei, 
TABLE 2 | Negative effects of CNMs in plant.

\begin{tabular}{|c|c|c|c|}
\hline Reference & CNM & Treatment & Effect \\
\hline Stampoulis et al., 2009 & MWCNT & Zucchini for 15 -day exposure to $1000 \mathrm{mg} / \mathrm{L}$ & $60 \%$ reduction in biomass reduction. \\
\hline Mondal et al., 2011 & Oxidized-MWCNT & Hydroponic mustard & Reduced germination and dry biomass. \\
\hline Liu et al., 2013 & ws $-\mathrm{C}_{70}$ & $\begin{array}{l}\text { Tobacco BY- } 2 \text { cells were exposed to } \\
0.01 \mathrm{mg} / \mathrm{mL} \text { ws }-\mathrm{C}_{70} \text { for } 3 \text { days in cell culture } \\
\text { medium. }\end{array}$ & $\begin{array}{l}\text { Cell boundary disruption and growth inhibition. Possible } \\
\text { adsorption of ws-C70 to the cell wall through } \\
\text { hydrostatic interaction with the carboxylic groups of } \\
\text { fullerenes. }\end{array}$ \\
\hline Begum et al., 2011 & $\begin{array}{l}\text { Water-soluble graphene } \\
\text { oxide (ws-GO) }\end{array}$ & $\begin{array}{l}\text { Lettuce, cabbage, Red spinach, and tomato } \\
\text { during a 20-days exposure }\end{array}$ & $\begin{array}{l}\text { At } 2000 \text { mg/L, significantly reduced plant growth (up to } \\
78 \% \text { ), biomass (up to } 88 \% \text { ), the number and size of } \\
\text { leaves (up to } 53 \text { and } 91 \% \text {, respectively), and increased } \\
\text { ROS along with necrotic symptoms. }\end{array}$ \\
\hline Anjum et al., 2013 & Graphene oxide (GO) & Vicia faba beans $100-1600 \mathrm{mg} / \mathrm{L}$ & $\begin{array}{l}\text { Concentration dependent decrease in oxidative enzyme } \\
\text { activity. }\end{array}$ \\
\hline Anjum et al., 2014 & Graphene oxide & Vicia faba beans 100-1600 mg/L & $\begin{array}{l}\text { Highest concentration (1600 mg/L) resulted in growth } \\
\text { reduction, decreased anti-oxidative enzyme activity } \\
\text { (e.g., catalase and ascorbate peroxidase), and greater } \\
\text { electrolyte leakage. }\end{array}$ \\
\hline
\end{tabular}

Co-contaminants

Hu et al., 2014

$\mathrm{GO}+$ Arsenic

$0.1-10 \mathrm{mg} / \mathrm{L} \mathrm{GO}$

Arsenic-GO co-exposure significantly reduced the fresh mass, shoot length, and chlorophyll content.

membrane damage, ROS generation, mitochondrial dysfunction, and induced cell death were observed upon exposure. Moreover, Anjum et al. (2013) evaluated the effect of GO on the fava bean (Vicia faba) glutathione redox system, a major determinant of cellular redox homeostasis. Concentration dependent stressresponse (order: $1600>200>100 \mathrm{mg} / \mathrm{L} \mathrm{GO}$ ), as well as decreased oxidative enzyme activity were observed. In a follow up study, Anjum et al. (2014) reported no toxicity below $800 \mathrm{mg} / \mathrm{L}$ of GO; the highest concentration $(1600 \mathrm{mg} / \mathrm{L})$ resulted in growth reduction, decreased anti-oxidative enzyme activity (e.g., catalase and ascorbate peroxidase), and greater electrolyte leakage.

Apart from CNTs and GOs, there are reports of fullerene toxicity to higher terrestrial plants. Liu et al. (2013) studied the effects of water-soluble carboxyfullerenes [ws- $\mathrm{C}_{70}$; $\left.\mathrm{C}_{70}\left(\mathrm{C}(\mathrm{COOH})_{2}\right)_{2-4}\right]$ in tobacco BY-2 cells (Nicotiana tobacum, cv. Bright Yellow). Here, BY-2 cells were exposed to $0.01 \mathrm{mg} / \mathrm{mL}$ ws $-\mathrm{C}_{70}$ for 3 days in cell culture medium. The results showed cell boundary disruption and growth inhibition, possibly due to the adsorption of ws- $\mathrm{C}_{70}$ to the cell wall through hydrostatic interaction with the carboxylic groups of fullerenes. In a coexposure study with GO and arsenate [As(V)], Hu et al. (2014) found that $0.1-10 \mathrm{mg} / \mathrm{L}$ GO exposure enhanced the adverse effects of $\mathrm{As}(\mathrm{V})$ in wheat seeds, significantly reducing the fresh mass, shoot length, and chlorophyll content of treated plants. In addition, the activity of peroxidase (POD) and superoxide dismutase (SOD), likely biomarkers for stress response, were increased in a concentration-dependent manner.

In summary, the negative effects exerted by the CNMs are specific to growth conditions and plant species. However, the limited and contradictory reports in the literature confounds the efforts to make consistent generalized observations with regard to CNM exposure. Clearly more research needs to be done to uncover the mechanisms of CNM-plant interactions and these fundamental studies should be conducted under a range of growth conditions and with a large number of plant species. Only then can one generalize/quantify potential negative effects in a way that would ensure safe wide-scale application of CNM under field conditions.

\section{EFFECTS OF CNMS ON PLANT-ASSOCIATED SOIL MICROBES}

Soil microbial communities have a direct impact on soil quality through processes such as nutrient cycling, decomposition of organic matter, and symbiotic relationships with terrestrial plant species (Kennedy and Smith, 1995). Therefore, protection of soil microbial biomass and diversity is a major challenge in agriculture. Currently, limited information is available on the interaction between CNTs and soil microbial community (Simonet and Valcarcel, 2009; Dinesh et al., 2012). CNMs may be directly toxic to soil microorganisms (Figure 3), may alter the bioavailability of nutrients, or may increase or reduce the toxicity of organic compounds and/or toxins (Dinesh et al., 2012). In addition, toxicity to plants may indirectly impact microbial communities. In this section, we review the current literature on the interactions of CNT with soil microbes; similar to the section on plants, we divide coverage of work into positive and negative impacts. Figure 4 summarizes the positive and negative impacts of the CNMs on the plants and the plant associated soilmicroorganisms.

\section{Positive Effects}

Although limited information is available, unlike plants, CNMs seem to be generally toxic to soil microbes (Table 3). Nevertheless, a few studies have revealed neutral or positive biological effects in soil microorganisms. For example, the impact 

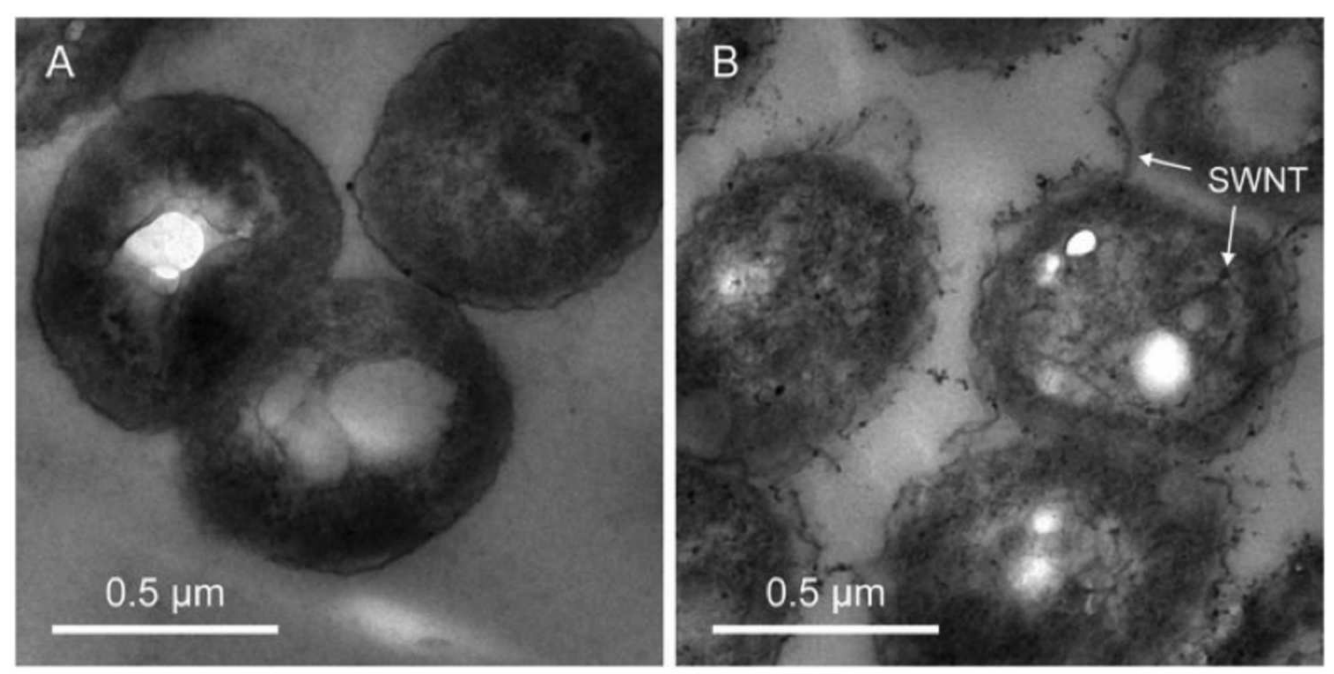

FIGURE 3 | Transmission electron microscopyTEM images of Paracoccus denitrificans cells in the absence (A) and presence of $50 \mathrm{mg} / \mathrm{L}$ carboxyl-modified SWNT (B) after 24 h of exposure. Zheng et al. (2014), Nature Publishing Group, a division of Macmillan Publishers Limited.

of fullerenes $\left(\mathrm{C}_{60}\right)$ on soil microbial community populations was evaluated using total phospholipid derived phosphate (Tong et al., 2007). Soil was treated with 1 and $1000 \mu \mathrm{g}$ $\mathrm{C}_{60} / \mathrm{g}$ soil for 180 days; the results showed that fullerenes had no impact on the structure or function of the soil microbial community or on soil enzymatic activities (Tong et al., 2007). Similarly, Nyberg et al. (2008) exposed anaerobic wastewater treatment sludge to fullerene $\left(\mathrm{C}_{60}\right)$ concentrations up to $50,000 \mathrm{mg} / \mathrm{kg}$ and showed no significant effects on microbial community activity after several months. Shrestha et al. (2013) reported diverse effects on soil (sandy loam) microbial communities after 90 days of exposure to MWCNT. The authors utilized a wide range of CNT concentrations $(10-10,000 \mathrm{mg} / \mathrm{kg})$; at lower concentrations $(10,100$, and $1000 \mathrm{mg} / \mathrm{kg}$ ), no observable effects were evidenced on soilmicrobial composition and enzymatic activities. However, at $10,000 \mathrm{mg} / \mathrm{kg}$ a mixed response was observed; decreased abundance was detected in select bacterial species (e.g., Waddlia, Holophaga, Derxia, and Opitutus). Notably, the amount of polycyclic aromatic hydrocarbon (PAH) degrading organisms (e.g., Cellulomonas, Rhodococcus, Pseudomonas, and Nocardioides) was markedly increased. These results suggest a potential shift toward more stress tolerant organisms with increasing soil-MWCNT concentration, although the findings are too limited to be conclusive. Additionally, Wang et al. (2013) showed that GO exposure at $0.1 \mathrm{~g} / \mathrm{L}$ enhanced the activity of anaerobic ammonium-oxidizing bacteria by $10 \%$. The authors reported a dose-dependent enhanced production of protein and carbohydrate with GO concentrations of $0.05-0.1 \mathrm{mg} / \mathrm{mL}$ (Wang et al., 2013). Although not related to plant species, Cordeiro et al. (2014) studied six bacterial colonies (Gram-negative) isolated from the mucus of the estuarine worm Laeonereis acuta (Nereididae), and showed no changes in the growth of the colonies after $24 \mathrm{~h}$ exposure to aqueous fullerene (aq- $\mathrm{C}_{60}$ ) suspensions at $0.01,0.10$, and $1.00 \mathrm{mg} / \mathrm{L}$. The mechanisms responsible for these interactions are unknown, however, this limited literature does suggest that under certain exposure scenarios, CNM hay have neutral or perhaps modestly beneficial effects on microbial communities.

\section{Negative Effects}

Although the mechanism of CNT toxicity is not well understood, possible antimicrobial activity has been observed (Table 4). It is evident that CNTs interact strongly with bacteria cell membranes; these strong electrostatic interactions may disrupt membrane structure integrity by oxidative stress and/or physical damage (puncture of membrane; Jackson et al., 2013). For example, studies with a range of bacteria (gram-negative Escherichia coli, Pseudomonas aeruginosa, and gram-positive Staphylococcus aureus, Bacillus subtilis) evaluated the toxicity of SWCNT dispersed $(5 \mathrm{~g} / \mathrm{mL})$ in Tween 20 saline solution in comparison with SWCNT aggregates in saline solution. Results showed a higher antibacterial activity of dispersed SWCNT to grampositive bacteria. The SWCNTs dispersed in Tween 20 saline solution showed antibacterial activity of $58.1 \pm 5.0 \%$ for E. coli, $65.1 \pm 1.8 \%$ for $P$. aeruginosa, $87.5 \pm 6.5 \%$ for B. subtilis, and $85.6 \pm 5.3 \%$ for S. aureus. On the other hand, SWCNTaggregates in saline solution showed reduced antibacterial activity of $33.8 \pm 4.0 \%$ for E. coli, $27.7 \pm 5.9 \%$ for P. aeruginosa, $53.9 \pm 2.8 \%$ for B. subtilis, and $50.3 \pm 3.5 \%$ for S. aureus. The authors reported that the enhanced antimicrobial activity was due to the smaller overall size and higher mobility in solution when compared with aggregates, which resulted in greater physical damage to bacterial membranes (Liu et al., 2009). Also, the antimicrobial activity of SWCNT has been reported on bacteria deposited on surfaces and in suspension (Jackson et al., 2013). Tong et al. (2012) quantitatively investigated the effects of surface coating of SWCNTs on soil microbial community under low and high organic matter concentration. Upon $6000 \mu \mathrm{g} / \mathrm{g}$ of functionalized SWNTs (fSWCNT; coated 


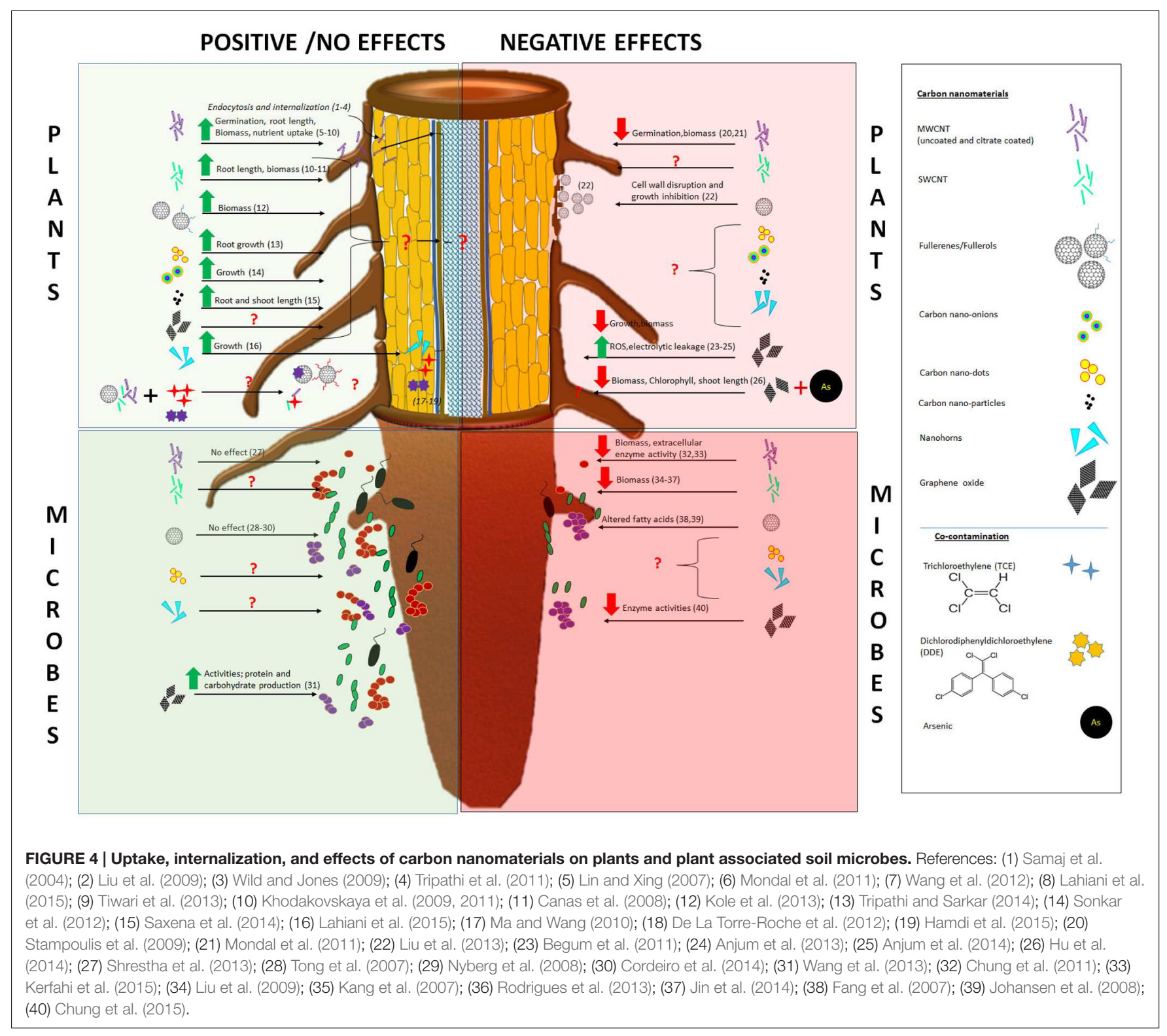

with polyethylene glycol or m-polyaminobenzene sulfonic acid) exposure for 6 weeks, researchers observed some microbial community shift keeping the total biomass unaffected. Studies with purified SWNTs (less than $0.8 \mathrm{wt} \%$ cobalt) at concentrations varying from 1 to $50 \mu \mathrm{g} / \mathrm{mL}$ exhibited strong antimicrobial properties to $E$. coli. Results indicated that direct contact of SWNT aggregates with $E$. coli cells caused loss of viability and subsequent inactivation. The authors also reported that toxicity was dependent on incubation/contact time with the SWNTs; the average of losses in viability were $73.1 \pm 5.4 \%, 79.9 \pm 9.8 \%$, and $87.6 \pm 4.7 \%$ at 30,60 , and $120 \mathrm{~min}$, respectively (Kang et al., 2007). Another important factor that may influence the toxicity of CNTs to bacteria is the presence of residual impurities. Commercial CNTs are synthesized with strong acids and contain up to $4.5-15 \%$ of metals such as cobalt $(\mathrm{Co})$, iron $(\mathrm{Fe})$, nickel $(\mathrm{Ni})$, and yttrium (Y) and other impurities, which may exert toxic effects on microbes (Kang et al., 2007; Petersen et al., 2014).

Another possible mechanism of CNT toxicity is the induction of ROS, which may then directly interact with organelles to induce DNA damage or protein inactivation that results in apoptosis and cell death (Jackson et al., 2013). Additionally, others have reported diverse toxic effects of carbon-based materials on soil bacteria. For example, Johansen et al. (2008) evaluated protozoans and bacterial total respiration, biomass, and diversity upon exposure to $\mathrm{C}_{60}$ fullerenes at $0-50 \mathrm{mg} / \mathrm{kg}$ dry soil. Results after 14 days showed a threefold decrease in the number of fast-growing bacteria (appearing 3 days after plating) after $\mathrm{C}_{60}$ exposure; while the protozoan population was only slightly (but not significantly) affected at the highest fullerene concentration (Johansen et al., 2008). 
TABLE 3 | Positive/Neutral effects of CNMs in soil microorganism.

\begin{tabular}{|c|c|c|c|c|}
\hline Reference & CNM & Organism & Treatment & Effect \\
\hline Tong et al., 2007 & Fullerene $\left(\mathrm{C}_{60}\right)$ & Microbial communities & $1 \mu \mathrm{g}$ and $1000 \mu \mathrm{g} \mathrm{C}_{60} / \mathrm{g}$ & $\begin{array}{l}\text { No impact on the structure or function } \\
\text { and enzymatic activities. }\end{array}$ \\
\hline Nyberg et al., 2008 & Fullerene $\left(\mathrm{C}_{60}\right)$ & Microbial communities & Up to $50,000 \mathrm{mg} / \mathrm{kg}$ & $\begin{array}{l}\text { No significant effects on microbial } \\
\text { community activity. }\end{array}$ \\
\hline \multirow[t]{2}{*}{ Shrestha et al., 2013} & MWCNT & Microbial communities & $10-100 \mathrm{mg} / \mathrm{kg}$ & $\begin{array}{l}\text { No observable effects on soil-microbial } \\
\text { composition and enzymatic activities at } \\
\text { lower concentrations. }\end{array}$ \\
\hline & & & $10,000 \mathrm{mg} / \mathrm{kg}$ & $\begin{array}{l}\text { Decreased abundance in select } \\
\text { bacterial species. }\end{array}$ \\
\hline \multirow[t]{2}{*}{ Wang et al., 2013} & Graphene oxide & Anaerobic ammonium-oxidizing bacteria & $0.1 \mathrm{~g} / \mathrm{L}$ & $\begin{array}{l}\text { Enhanced activity of anaerobic } \\
\text { ammonium-oxidizing bacteria by } 10 \% \text {. }\end{array}$ \\
\hline & & & $0.05-0.1 \mathrm{mg} / \mathrm{ml}$ & $\begin{array}{l}\text { Enhanced production of protein and } \\
\text { carbohydrate. }\end{array}$ \\
\hline Cordeiro et al., 2014 & Fullerene $\left(\mathrm{C}_{60}\right)$ & Gram-negative bacterial colonies & $0.01,0.10$, and $1.00 \mathrm{mg} / \mathrm{L}$ & $\begin{array}{l}\text { No changes in the growth of the } \\
\text { colonies after } 24 \mathrm{~h} \text { exposure. }\end{array}$ \\
\hline
\end{tabular}

TABLE 4 | Negative effects of CNMs in soil microorganism.

\begin{tabular}{|c|c|c|c|c|}
\hline Reference & CNM & Organism & Treatment & Effect \\
\hline Kang et al., 2007 & SWNTS & Escherichia coli & $1-50 \mu \mathrm{g} / \mathrm{mL}$ & Strong antimicrobial properties. \\
\hline Fang et al., 2007 & $\mathrm{C}_{60}$ aggregates & $\begin{array}{l}\text { Bacillus subtilis (Gram-positive) } \\
\text { and Pseudomonas putida } \\
\text { (Gram-negative) }\end{array}$ & $0.01 \mathrm{mg} / \mathrm{L}$ & $\begin{array}{l}\text { Significantly impacted levels of iso-and } \\
\text { anteiso-branched fatty acids in Bacillus subtilis } \\
\text { (Gram-positive). }\end{array}$ \\
\hline \multirow[t]{2}{*}{ Johansen et al., 2008} & \multirow[t]{2}{*}{ Fullerenes $\mathrm{C}_{60}$} & \multirow[t]{2}{*}{$\begin{array}{l}\text { Microbial communities and } \\
\text { protozoans }\end{array}$} & \multirow[t]{2}{*}{$0-50 \mathrm{mg} / \mathrm{kg}$} & $\begin{array}{l}\text { Results after } 14 \text { days showed a threefold } \\
\text { decrease in the number of fast-growing } \\
\text { bacteria. }\end{array}$ \\
\hline & & & & No significant changes in protozoan population. \\
\hline Liu et al., 2009 & $\begin{array}{l}\text { SWCNT dispersed and } \\
\text { SWCNT agglomerates in } \\
\text { saline solution }\end{array}$ & $\begin{array}{l}\text { Gram-negative Escherichia coli, } \\
\text { Pseudomonas aeruginosa, and } \\
\text { gram-positive Staphylococcus } \\
\text { aureus, Bacillus subtilis }\end{array}$ & $5 \mathrm{~g} / \mathrm{mL}$ & $\begin{array}{l}\text { Higher antibacterial activity of dispersed SCNT } \\
\text { to gram-positive bacteria in comparison with } \\
\text { the agglomerates. }\end{array}$ \\
\hline \multirow[t]{2}{*}{ Chung et al., 2011} & \multirow[t]{2}{*}{ MWCNT } & \multirow[t]{2}{*}{ Microbial communities } & \multirow[t]{2}{*}{$\begin{array}{l}0,50,500, \text { and } \\
5000 \mu \mathrm{g} / \mathrm{g}\end{array}$} & $\begin{array}{l}\text { Enzyme activity decreased after } 30 \text { min of the } \\
\text { incubation. }\end{array}$ \\
\hline & & & & $\begin{array}{l}\text { Microbial biomass and extracellular enzyme } \\
\text { activity decreased (up to } ~ 50 \% \text { ). }\end{array}$ \\
\hline \multirow[t]{2}{*}{ Rodrigues et al., 2013} & \multirow[t]{2}{*}{$\begin{array}{l}\text { Carboxyl-functionalized } \\
\text { SWCNTs }\end{array}$} & \multirow[t]{2}{*}{$\begin{array}{l}\text { Bacterial and fungal } \\
\text { communities }\end{array}$} & \multirow[t]{2}{*}{$0.5 \mathrm{mg} / \mathrm{L}$} & $\begin{array}{l}\text { Alteration on Pseudomonas putida } \\
\text { (Gram-negative) phase transition temperatures } \\
\text { and levels of unsaturated fatty acids. }\end{array}$ \\
\hline & & & & $\begin{array}{l}\text { Higher doses had a maximum biomass loss at } \\
3 \text { days and the fungal community was unable } \\
\text { to recover even after } 14 \text { days. }\end{array}$ \\
\hline Jin et al., 2014 & SWCNT & $\begin{array}{l}\text { Gram- positive, Gram-negative } \\
\text { bacteria, and fungal } \\
\text { populations }\end{array}$ & 0.03 to $1 \mathrm{mg} / \mathrm{g}$ & $\begin{array}{l}\text { Decreased biomass of microbial groups and } \\
\text { fungal populations. }\end{array}$ \\
\hline Chung et al., 2015 & Graphene oxide & $\begin{array}{l}\text { Microbial communities/soil } \\
\text { enzymes }\end{array}$ & $0.5-1 \mathrm{mg} / \mathrm{kg}$ & $\begin{array}{l}\text { Decreases of up to } 50 \% \text { in the enzyme } \\
\text { activities after } 21 \text { days of incubation. }\end{array}$ \\
\hline Kerfahi et al., 2015 & $\begin{array}{l}\text { Raw and acid treated or } \\
\text { functionalized MWCNTS }\end{array}$ & Microbial communities & $0-5000 \mathrm{mg} / \mathrm{kg}$ & $\begin{array}{l}\text { Bacterial community composition was affected } \\
\text { but recovered after } 8 \text { weeks. }\end{array}$ \\
\hline
\end{tabular}

Fang et al. (2007) showed that $\mathrm{C}_{60}$ aggregates in water at $0.01 \mathrm{mg} / \mathrm{L}$ significantly increased the levels of iso-and anteisobranched fatty acids from 5.8 to $31.5 \%$ and 12.9 to $32.3 \%$ in B. subtilis (Gram-positive), suggesting an increase in membrane fluidity as an adaptation response to $\mathrm{C}_{60}$. Alternatively, the aq$\mathrm{C}_{60}$ at $0.5 \mathrm{mg} / \mathrm{L}$ resulted in an alteration on P. putida's (Gramnegative) phase transition temperatures and levels of unsaturated fatty acids from bacterial membrane. Rodrigues et al. (2013) reported the effect of carboxyl-functionalized SWCNTs on soil bacterial and fungal communities. Soil was amended with 0 , 250 , and $500 \mathrm{mg} / \mathrm{kg}$ functionalized SWCNT for 14 days and the populations were monitored over time. The authors reported that after 3 days, the number of colony-forming units (CFUs) was significantly decreased but that the population had recovered after 14 days. Alternatively, higher doses of SWNTs had a similar biomass loss at 3 days but the fungal community was 
unable to recover even after 14 days. Similarly, Jin et al. (2014) reported that at relatively low concentrations $(0.03-1 \mathrm{mg} / \mathrm{g}$ ), the biomass of gram-positive and gram-negative bacteria, as well as fungal populations, showed a negative correlation with SWCNT concentration in soil. Additionally, in a 3-week study, the authors reported that SWCNTs showed similar toxicological responses to MWCNTs but at five-times lower concentrations due to the higher surface area of single wall tubes (Jin et al., 2013). Chung et al. (2011) investigated the effect of MWCNT on the microbial communities treated with $0,50,500$, and $5000 \mu \mathrm{g} / \mathrm{g}$ MWCNT in two different soil types (sandy loam and loamy sand) for $30 \mathrm{~min}, 1,4$, and 11 days. The enzyme activity decreased at $30 \mathrm{~min}$ of incubation and for most enzymes, the suppression persisted until day 11. In both soils, microbial biomass and extracellular enzyme activity decreased (up to $\sim 50 \%$ ) and reductions were more notable at higher exposure concentrations (500 and $5000 \mu \mathrm{g} / \mathrm{g}$ ). Recently, Kerfahi et al. (2015) investigated the effects of native and functionalized MWCNTs (0-5000 mg/kg) on soil bacterial. The authors reported that at 2 weeks, the soil bacterial community composition was affected by the fMWCNT at the highest concentrations; however, after 8 weeks there was no effect on the bacterial diversity with either type of nanotube. The authors attributed this early effect to the acidic nature of fMWCNTs, which caused a decrease in soil $\mathrm{pH}$ at higher exposure concentrations and subsequently changed (temporarily) soil bacterial communities (Kerfahi et al., 2015). Chung et al. (2015) studied the impact of GO at $0.5-1 \mathrm{mg} / \mathrm{kg}$ and noted a decrease up to $50 \%$ in the activity of select key soil enzymes, including xylosidase, 1,4- $ß-\mathrm{N}$-acetyl glucosaminidase and phosphatase after 21 days of exposure. Clearly, the published literature suggests that CNMs may have a significant negative effect on soil microbial communities (Figure 4). However, there is limited information on the broader impacts of these adverse effects, including implications for symbiotic or co-habitating terrestrial plant species. Figure 4 also highlights the gaps in the literature with respect to uptake and internalization of the CNMs, as well as their effects on the soil biota.

\section{LIMITATIONS AND FUTURE PERSPECTIVE}

\section{Non-Environmentally Relevant Growth Conditions}

Considering the varied applications of CNTs and their scope of use in agriculture, it is necessary to design realistic exposure scenarios to investigate CNM fate and effects. This includes testing environmentally realistic concentrations under relevant environmental conditions. In looking at the existing literature, it is clear that for obvious reasons, neither of these parameters have been met. To date, there is still lack of knowledge on the amount of nanomaterials released into the environment. Modeling studies have predicted that CNT concentrations in waste water treatment plant effluent in the San Francisco Bay area are approximately $0.01-0.05 \mu \mathrm{g} / \mathrm{L}$, while in dry biosolids the levels range from 0.05 to $0.1 \mu \mathrm{g} / \mathrm{kg}$ (Keller et al., 2013).
Gottschalk et al. (2009) used a model-based on probabilistic material flow analysis to estimate the CNT concentrations in US sludge-treated soils were $0.4 \mu \mathrm{g} / \mathrm{kg}$. Other studies have predicted the environmental concentration of additional NMs (Gottschalk et al., 2009); these estimates coincide with the range of predicted concentrations for CNTs in the environment. Importantly, the vast majority of the existing nanotoxicology literature has used exposure concentrations that are few orders of magnitude above than predicted to currently exist. For example, commonly used concentrations in soil studies range from 10 to $5,000 \mathrm{mg} / \mathrm{kg}$ (De La Torre-Roche et al., 2013; Shrestha et al., 2013), while in hydroponic studies concentrations vary from $2.3 \mu \mathrm{g} / \mathrm{L}$ to $5000 \mathrm{mg} / \mathrm{L}$ (Canas et al., 2008; Mondal et al., 2011). Although, such 'high' exposure concentrations are useful for comparative analysis of inherent NM toxicity, the data is often inappropriate for broader estimations of actual risk. Another major confounding factor in the current literature is the general lack of soil-based studies with regard to CNT fate and effects. The complex interactions of CNT with NOMs and/or pollutants in soil are noted above and can have significant effects on material fate, behavior, and toxicity in the environment. From analytical perspective, it is also very difficult to quantify CNMs at very low levels $(\mu \mathrm{g} / \mathrm{kg}$ or $\mu \mathrm{g} / \mathrm{L})$ under high background concentration of organic carbon and other organic/inorganic compounds coming from NOMs. Moreover, sample collection, transportation, preservation can produce significant artifacts on CNMs. Additionally, many published studies use "neat" or "pristine" CNTs, which fails to recognize the importance of weathering and transformation in soil, as well as the fact that in most applications, CNTs will be a component of a larger and more complex polymer or formulation. In fact, only a few studies have used acid-treated CNT that are commonly used in industry and are expected to be present in the environment where interactions with soil and biota will occur (Kerfahi et al., 2015). Since laboratory based recent studies will likely lead to inaccurate predictions of CNT fate and effects, assessment under "realistic" conditions and in more complex and relevant biological scenarios is greatly needed to appropriately assess the risk from the widespread CNT in agricultural settings.

\section{Lack of Mechanistic Understanding}

Not surprisingly, our review of the existing literature has revealed that majority of research on CNM-toxicity is focused on straight-forward evaluation of physiological and biochemical effects. The interaction among various environmental parameters (growth media, exposure time, and receptor/species differences) and CNMs (type, synthesis conditions, and concentrations) are complex and efforts to ascertain consistent or broad trends with regard to material fate and effects is difficult. In addition, artifacts arising from sample preparation, storage, and/or experimental design can confound results and lead to biased or inaccurate data interpretation (Petersen et al., 2014). Importantly, little progress has been made on understanding the underlying mechanisms of toxicity at the molecular/genetic level. The reasons for the lack of study at this scale are numerous and include the: (i) current technological limitations to detecting CNMs in complex growth media, (ii) unavailability of in situ real-time monitoring 
techniques to track CNMs inside the living tissues and different environmental components, (iii) complex, heterogeneous, and inconsistent nature of the soil matrix, (iv) lack of knowledge of the distribution of CNMs in the environment, and (v) species and growth condition dependency of the CNM induced toxicity. Additionally, in the growth media, during exposure, the NM surface properties may get altered, which can subsequently cause changes in material bioavailability and toxicological outcomes (Mukherjee et al., 2014a,b; Servin et al., 2015). On the other side, the impact of agricultural feedstock on nanomaterial synthesis, structure, and reactivity still remains elusive. There are few reports where organic extracts from agricultural plants, e.g., grass and tea, among others, has been successfully used as the alternative carbon sources for CNM green-synthesis in-situ (Ruan et al., 2011; Jacob et al., 2015). Nonetheless, the mechanistic understanding of this bottomup approach remains mostly unknown and needs further investigation.

Three major modes of action for NMs interaction are known: (i) dissolution (Bandyopadhyay et al., 2015), (ii) direct contact (Zhao et al., 2013, 2014), and (iii) co-transport of other contaminants (De La Torre-Roche et al., 2012, 2013; Lynch et al., 2014). Pristine CNMs are resistant to dissolution (Garner et al., 2015); however, functionalized CNMs such as carboxylated-CNTs and $\mathrm{C}_{60}-\mathrm{OH}$ are much more likely to dissolve in the growth media (Kole et al., 2013; Saxena et al., 2014). Toxic heavy metals (e.g., Ni, Co, and Fe) associated with CNMs (mostly CNTs) could also alter the overall toxicological profile (Liu et al., 2007). Therefore, a comprehensive knowledge of the dissolution/degradation kinetics of the CNMs in the environment is necessary to understand the underlying mechanistic pathways. Additionally, direct physical contact has been shown to alter plant physiological and biochemical parameters such as biomass production, growth, germination rates, and ROS production. Last, there are several studies in the literature demonstrating CNM mediated alteration of pesticide uptake/toxicity in terrestrial plants, including zucchini, soybean, tomato, lettuce etc. (De La Torre-Roche et al., 2012; Hamdi et al., 2015).

Unlike metallic NMs, there are very few robust analytical methods available for detecting CNM in the environment (Petersen et al., 2011; Bandyopadhyay et al., 2012a,b, 2013; Guo et al., 2015). The environmentally relevant concentration of CNMs can go down to as low as $0.05 \mu \mathrm{g} / \mathrm{kg}$ (Keller et al., 2013). Researchers use various analytical techniques, e.g., TEM, SEM, AFM, and Raman spectroscopy, among others, to determine the presence of CNMs inside the plant tissue. These techniques are capable of identifying compounds up to sub-nanometer level. However, imaging techniques, e.g., TEM and SEM need extensive sample preparation (e.g., solid-phase extraction, liquidliquid extraction, fixation, staining, etc.), which can alter the morphology of individual CNMs or their clusters (Petersen et al., 2014). Moreover, softer imaging techniques, e.g., Raman spectroscopy (with high wavelength laser) might lead to surface modification of the CNMs. Therefore, technological limitation is clearly evident and much focus needs to be directed toward the development of imaging technologies with very little or no prior sample preparation without compromising the sub-nanometer resolution.

\section{CONCLUSION}

From the above discussion, it is clear that a general lack of understanding persists for CNM fate and effects in the environment. The somewhat limited literature that does exist is mixed for most species, with both positive and negative effects being observed. The reasons for these mixed effects are numerous (different exposure scenarios, growth conditions, particle type/concentration, and species, among others). As such, reliable and accurate assessment of risk, which is necessary before widespread application of CNMs in agriculture, is not possible with the current knowledge base. Only comprehensive investigations of chronic exposure under environmentally realistic scenarios will enable such efforts. Future research should also focus on molecular/genetic-level studies under environmentally relevant conditions. Information gained from whole genome/proteome/metabolome analyses of different organisms (model organism or crop species) could prove to be a powerful resource for assessing the risks of CNM-exposure and potentially shedding light on the key factors involved in the mechanisms of cellular response to uptake and storage. Effects of CNMs on soil bacterial populations (in terms of modification in relative abundance of different species or isolation of hypersensitive/tolerant strains), coupled with more efficient characterization of the interactions between CNMs and organic/inorganic matter present in soil, can add further information in a more relevant context of a biological "realistic" scenario. This will inherently increase the complexity of the studies and, at the same time, decrease the gap between experimental and environmental conditions.

\section{AUTHOR CONTRIBUTIONS}

AM, SM, AS, LP, OD, and JW collected data from the literature and drafted the manuscript. All the authors wrote and revised the article.

\section{ACKNOWLEDGMENTS}

JW acknowledges USDA-AFRI (\#2011-67006-30181) and LP acknowledges University of Parma Research Fellowship n. 3BIOS/2014 entitled "Analisi sulla sicurezza per la salute e per l'ambiente determinata dalle interazioni tra nanoparticelle, nanomateriali e piante di interesse agroalimentare" and Professor's Nelson Marmiroli, Marta Marmiroli, and Elena Maestri of the University of Parma. 


\section{REFERENCES}

Anjum, N. A., Singh, N., Singh, M. K., Sayeed, I., Duarte, A. C., Pereira, E., et al. (2014). Single-bilayer graphene oxide sheet impacts and underlying potential mechanism assessment in germinating faba bean (Vicia faba L.). Sci. Total Environ. 472, 834-841. doi: 10.1016/j.scitotenv.2013.11.018

Anjum, N. A., Singh, N., Singh, M. K., Shah, Z. A., Duarte, A. C., Pereira, E., et al. (2013). Single-bilayer graphene oxide sheet tolerance and glutathione redox system significance assessment in faba bean (Vicia faba L.). J. Nanopart. Res. 15:1770. doi: 10.1016/j.scitotenv.2013.11.018

Avanasi, R., Jackson, W. A., Sherwin, B., Mudge, J. F., and Anderson, T. A. (2014). C60 fullerene soil sorption. Biodegradation, and plant uptake. Environ. Sci. Technol. 48, 2792-2797. doi: 10.1021/es405306w

Bandyopadhyay, S., Peralta-Videa, J. R., and Gardea-Torresdey, J. L. (2013). Advanced analytical techniques for the measurement of nanomaterials in food and agricultural samples: a review. Environ. Eng. Sci. 30, 118-125. doi: 10.1089/ees.2012.0325

Bandyopadhyay, S., Peralta-Videa, J. R., Hernandez-Viezcas, J. A., Montes, M. O., Keller, A. A., and Gardea-Torresdey, J. L. (2012a). Microscopic and spectroscopic methods applied to the measurements of nanoparticles in the environment. Appl. Spectrosc. Rev. 47, 180-206. doi: 10.1080/05704928.2011.637186

Bandyopadhyay, S., Peralta-Videa, J. R., Plascencia-Villa, G., José-Yacamán, M., and Gardea-Torresdey, J. L. (2012b). Comparative toxicity assessment of $\mathrm{CeO}_{2}$ and $\mathrm{ZnO}$ nanoparticles towards Sinorhizobium meliloti, a symbiotic alfalfa associated bacterium: use of advanced microscopic and spectroscopic techniques. J. Hazard. Mater. 241-242, 379-386. doi: 10.1016/j.jhazmat.2012.09.056

Bandyopadhyay, S., Plascencia-Villa, G., Mukherjee, A., Rico, C. M., JoséYacamán, M., Peralta-Videa, J. R., et al. (2015). Comparative phytotoxicity of $\mathrm{ZnO} \mathrm{NPs}$, bulk $\mathrm{ZnO}$, and ionic zinc onto the alfalfa plants symbiotically associated with Sinorhizobium meliloti in soil. Sci. Total Environ. 515-516, 60-69. doi: 10.1016/j.scitotenv.2015.02.014

Baptista, F. R., Belhout, S. A., Giordani, S., and Quinn, S. J. (2015). Recent developments in carbon nanomaterial sensors. Chem. Soc. Rev. 44, 4433-4453. doi: $10.1039 / \mathrm{c} 4 \mathrm{cs} 00379 \mathrm{a}$

Bartelmess, J., and Giordani, S. (2014). Carbon nano-onions (multi-layer fullerenes): chemistry and applications. Beilstein J. Nanotechnol. 5, 1980-1998. doi: 10.3762/bjnano. 5.207

Basch, E., Gabardi, S., and Ulbricht, C. (2003). Bitter melon (Momordica charantia): a review of efficacy and safety. Am. J. Health Syst. Pharm. 60, 356-359.

Begum, P., and Fugetsu, B. (2013). Induction of cell death by graphene in Arabidopsis thaliana (Columbia ecotype) T87 cell suspensions. J. Hazard. Mater. 260, 1032-1041. doi: 10.1016/j.jhazmat.2013.06.063

Begum, P., Ikhtiari, R., and Fugetsu, B. (2011). Graphene phytotoxicity in the seedling stage of cabbage, tomato, red spinach, and lettuce. Carbon 49, 39073919. doi: 10.1016/j.carbon.2011.05.029

Bello, D., Wardle, B. L., Yamamoto, N., deVilloria, R. G., Garcia, E. J., Hart, A. J., et al. (2009). Exposure to nanoscale particles and fibers during machining of hybrid advanced composites containing carbon nanotubes. J. Nanopart. Res. 11, 231-249. doi: 10.1007/s11051-008-9499-4

Benn, T. M., Westerhoff, P., and Herckes, P. (2011). Detection of fullerenes (C60 and C70) in commercial cosmetics. Environ. Pollut. 159, 1334-1342. doi: 10.1016/j.envpol.2011.01.018

Bennett, S. W., Adeleye, A., Ji, Z., and Keller, A. A. (2013). Stability, metal leaching, photoactivity and toxicity in freshwater systems of commercial single wall carbon nanotubes. Water Res. 47, 4074-4085. doi: 10.1016/j.watres.2012. 12.039

Bergmann, C. P., and Machado, F. (2015). Carbon Nanomaterials as Adsorbents for Environmental and Biological Applications (Berlin: Springer), 1-122.

Canas, J. E., Long, M., Nations, S., Vadan, R., Dai, L., Luo, M., et al. (2008). Effects of functionalized and nonfunctionalized single-walled carbon nanotubes on root elongation of select crop species. Environ. Toxicol. Chem. 27, 1922-1931. doi: 10.1897/08-117.1

Cha, C., Shin, S. R., Annabi, N., Dokmeci, M. R., and Khademhosseini, A. (2013). Carbon-based nanomaterials: multifunctional materials for biomedical engineering. ACS Nano 7, 2891-2897. doi: 10.1021/nn401196a
Chichiriccò, G., and Poma, A. (2015). Penetration and toxicity of nanomaterials in higher plants. Nanomaterials 5, 851-873. doi: 10.3390/nano5020851

Chung, H., Kim, M. J., Ko, K., Kim, J. H., Kwon, H. A., Hong, I., et al. (2015). Effects of graphene oxides on soil enzyme activity and microbial biomass. Sci. Total Environ. 514, 307-313. doi: 10.1016/j.scitotenv.2015.01.077

Chung, H., Son, Y., Yoon, T. K., Kim, S., and Kim, W. (2011). The effect of multiwalled carbon nanotubes on soil microbial activity. Ecotoxicol. Environ. Saf. 74, 569-575. doi: 10.1016/j.ecoenv.2011.01.004

Cordeiro, L. F., Marques, B. F., Kist, L. W., Bogo, M. R., Lopez, G., Pagano, G., et al. (2014). Toxicity of fullerene and nanosilver nanomaterials against bacteria associated to the body surface of the estuarine worm Laeonereis acuta (Polychaeta. Nereididae). Mar. Environ. Res. 99, 52-59. doi: 10.1016/j.marenvres.2014.05.011

De La Torre-Roche, R., Hawthorne, J., Deng, Y., Xing, B., Cai, W., Newman, L. A., et al. (2012). Fullerene-enhanced accumulation of p,p'-DDE in agricultural crop species. Environ. Sci. Technol. 46, 9315-9323. doi: 10.1021/es301982w

De La Torre-Roche, R., Hawthorne, J., Deng, Y., Xing, B., Cai, W., Newman, L. A., et al. (2013). Multiwalled carbon nanotubes and c60 fullerenes differentially impact the accumulation of weathered pesticides in four agricultural plants. Environ. Sci. Technol. 47, 12539-12547. doi: 10.1021/es4034809

De Volder, M. F., Tawfick, S. H., Baughman, R. H., and Hart, A. J. (2013). Carbon nanotubes: present and future commercial applications. Science 339, 535-539. doi: $10.1126 /$ science. 1222453

Dinesh, R., Anandaraj, M., Srinivasan, V., and Hamza, S. (2012). Engineered nanoparticles in the soil and their potential implications to microbial activity. Geoderma 173-174, 19-27. doi: 10.1016/j.geoderma.2011.12.018

Fang, J., Lyon, D. Y., Wiesner, M. R., Dong, J., and Alvarez, P. J. (2007). Effect of a fullerene water suspension on bacterial phospholipids and membrane phase behavior. Environ. Sci. Technol. 41, 2636-2642. doi: 10.1021/es 062181w

Garner, K. L., Suh, S., Lenihan, H. S., and Keller, A. A. (2015). Species sensitivity distributions for engineered nanomaterials. Environ. Sci. Technol. 49, 57535759. doi: 10.1021/acs.est.5b00081

Georgakilas, V., Perman, J. A., Tucek, J., and Zboril, R. (2015). broad family of carbon nanoallotropes: classification, chemistry, and applications of fullerenes, carbon dots, nanotubes, graphene, nanodiamonds, and combined superstructures. Chem. Rev. 115, 4744-4822. doi: 10.1021/cr5 $00304 \mathrm{f}$

Ghosh, M., Bhadra, S., Adegoke, A., Bandyopadhyay, M., and Mukherjee, A. (2015). MWCNT uptake in Allium cepa root cells induces cytotoxic and genotoxic responses and results in DNA hyper-methylation. Mutat. Res. 774, 49-58. doi: 10.1016/j.mrfmmm.2015.03.004

Gottschalk, F., Sonderer, T., Scholz, R. W., and Nowack, B. (2009). Modeled environmental concentrations of engineered nanomaterials ( $\mathrm{TiO}(2), \mathrm{ZnO}, \mathrm{Ag}$, CNT, Fullerenes) for different regions. Environ. Sci. Technol. 43, 9216-9222. doi: $10.1021 /$ es 9015553

Guo, H., Zhang, Z., Xing, B., Mukherjee, A., Musante, C., White, J. C., et al. (2015). Analysis of silver nanoparticles in antimicrobial products using surfaceenhanced raman spectroscopy (SERS). Environ. Sci. Technol. 49, 4317-4324. doi: $10.1021 /$ acs.est.5b00370

Hamdi, H., De La Torre-Roche, R., Hawthorne, J., and White, J. C. (2015). Impact of non-functionalized and amino-functionalized multiwall carbon nanotubes on pesticide uptake by lettuce (Lactuca sativa L.). Nanotoxicology 9, 172-180. doi: $10.3109 / 17435390.2014 .907456$

Hong, G., Diao, S., Antaris, A. L., and Dai, H. (2015). Carbon nanomaterials for biological imaging and nanomedicinal therapy. Chem. Rev. 115, 10816-10906. doi: 10.1021/acs.chemrev.5b00008

Hu, X., Kang, J., Lu, K., Zhou, R., Mu, L., and Zhou, Q. (2014). Graphene oxide amplifies the phytotoxicity of arsenic in wheat. Sci. Rep. 4:6122. doi: $10.1038 /$ srep06122

Hurt, R. H., Monthioux, M., and Kane, A. (2006). Toxicology of carbon nanomaterials: status, trends, and perspectives on the special issue. Carbon 44, 1028-1033. doi: 10.1016/j.carbon.2005.12.023

Husen, A., and Siddiqi, K. S. (2014). Carbon and fullerene nanomaterials in plant system. J. Nanobiotechnol. 12:16. doi: 10.1186/1477-3155-12-16

Hyung, H., Fortner, J. D., Hughes, J. B., and Kim, J. H. (2007). Natural organic matter stabilizes carbon nanotubes in the aqueous phase. Environ. Sci. Technol. 41, 179-184. doi: $10.1021 / \mathrm{es} 061817 \mathrm{~g}$ 
Hyung, H., and Kim, J. H. (2008). Natural organic matter (NOM) adsorption to multi-walled carbon nanotubes: effect of NOM characteristics and water quality parameters. Environ. Sci. Technol. 42, 4416-4421. doi: 10.1021/es702916h

Jackson, P., Jacobsen, N. R., Baun, A., Birkedal, R., Kuhnel, D., Jensen, K. A., et al. (2013). Bioaccumulation and ecotoxicity of carbon nanotubes. Chem. Cent. J. 7:154. doi: 10.1186/1752-153X-7-154

Jacob, M. V., Rawat, R. S., Ouyang, B., Bazaka, K., Kumar, D. S., Taguchi, D., et al. (2015). Catalyst-free plasma enhanced growth of graphene from sustainable sources. Nano Lett. 15, 5702-5708. doi: 10.1021/acs.nanolett.5b01363

Jin, L., Son, Y., Deforest, J. L., Kang, Y. J., Kim, W., and Chung, H. (2014). Singlewalled carbon nanotubes alter soil microbial community composition. Sci. Total Environ. 466-467, 533-538. doi: 10.1016/j.scitotenv.2013.07.035

Jin, L., Son, Y., Yoon, T. K., Kang, Y. J., Kim, W., and Chung, H. (2013). High concentrations of single-walled carbon nanotubes lower soil enzyme activity and microbial biomass. Ecotoxicol. Environ. Saf. 88, 9-15. doi: 10.1016/j.ecoenv.2012.10.031

Johansen, A., Pedersen, A. L., Jensen, K. A., Karlson, U., Hansen, B. M., ScottFordsmand, J. J., et al. (2008). Effects of C60 fullerene nanoparticles on soil bacteria and protozoans. Environ. Toxicol. Chem. 27, 1895-1903. doi: 10.1897/07-375.1

Kang, S., Pinault, M., Pfefferle, L. D., and Elimelech, M. (2007). Single-walled carbon nanotubes exhibit strong antimicrobial activity. Langmuir 23, 86708673. doi: 10.1021/la701067r

Keller, A. A., Mcferran, S., Lazareva, A., and Suh, S. (2013). Global life cycle releases of engineered nanomaterials. J. Nanopart. Res. 15:1692. doi: 10.1007/s11051013-1692-4

Kennedy, A. C., and Smith, K. L. (1995). Soil microbial diversity and the sustainability of agricultural soils. Plant Soil 170, 75-86. doi: 10.1007/bf02183056

Kerfahi, D., Tripathi, B. M., Singh, D., Kim, H., Lee, S., Lee, J., et al. (2015). Effects of functionalized and raw multi-walled carbon nanotubes on soil bacterial community composition. PLOS ONE 10:e0123042. doi: 10.1371/journal.pone.0123042

Khodakovskaya, M., Dervishi, E., Mahmood, M., Xu, Y., Li, Z., Watanabe, F., et al. (2009). Carbon nanotubes are able to penetrate plant seed coat and dramatically affect seed germination and plant growth. ACS Nano 3, 3221-3227. doi: $10.1021 / \mathrm{nn} 900887 \mathrm{~m}$

Khodakovskaya, M. V., De Silva, K., Biris, A. S., Dervishi, E., and Villagarcia, H. (2012). Carbon nanotubes induce growth enhancement of tobacco cells. ACS Nano 6, 2128-2135. doi: 10.1021/nn204643g

Khodakovskaya, M. V., De Silva, K., Nedosekin, D. A., Dervishi, E., Biris, A. S., Shashkov, E. V., et al. (2011). Complex genetic, photothermal, and photoacoustic analysis of nanoparticle-plant interactions. Proc. Natl. Acad. Sci. U.S.A. 108, 1028-1033. doi: 10.1073/pnas. 1008856108

Khot, L. R., Sankaran, S., Maja, J. M., Ehsani, R., and Schuster, E. W. (2012). Applications of nanomaterials in agricultural production and crop protection: a review. Crop Protect. 35, 64-70. doi: 10.1016/j.cropro.2012. 01.007

Kole, C., Kole, P., Randunu, K. M., Choudhary, P., Podila, R., Ke, P. C., et al. (2013). Nanobiotechnology can boost crop production and quality: first evidence from increased plant biomass, fruit yield and phytomedicine content in bitter melon (Momordica charantia). BMC Biotechnol. 13:37. doi: 10.1186/14726750-13-37

Lahiani, M. H., Chen, J., Irin, F., Puretzky, A. A., Green, M. J., and Khodakovskaya, M. V. (2015). Interaction of carbon nanohorns with plants: uptake and biological effects. Carbon 81, 607-619. doi: 10.1016/j.carbon.2014.09.095

Lahiani, M. H., Dervishi, E., Chen, J., Nima, Z., Gaume, A., Biris, A. S., et al. (2013). Impact of carbon nanotube exposure to seeds of valuable crops. ACS Appl. Mater Interfaces 5, 7965-7973. doi: 10.1021/am402052x

Lecoanet, H. F., Bottero, J. Y., and Wiesner, M. R. (2004). Laboratory assessment of the mobility of nanomaterials in porous media. Environ. Sci. Technol. 38, 5164-5169. doi: 10.1021/es0352303

Lin, D., and Xing, B. (2007). Phytotoxicity of nanoparticles: inhibition of seed germination and root growth. Environ. Pollut. 150, 243-250. doi: 10.1016/j.envpol.2007.01.016

Lin, S., Reppert, J., Hu, Q., Hudson, J. S., Reid, M. L., Ratnikova, T. A., et al. (2009). Uptake, translocation, and transmission of carbon nanomaterials in rice plants. Small 5, 1128-1132. doi: 10.1002/smll.200801556
Liu, Q., Chen, B., Wang, Q., Shi, X., Xiao, Z., Lin, J., et al. (2009). Carbon nanotubes as molecular transporters for walled plant cells. Nano Lett. 9, 1007-1010. doi: $10.1021 / \mathrm{nl} 803083 \mathrm{u}$

Liu, Q., Zhang, X., Zhao, Y., Lin, J., Shu, C., Wang, C., et al. (2013). FullereneINDUCED increase of glycosyl residue on living plant cell wall. Environ. Sci. Technol. 47, 7490-7498. doi: 10.1021/es4010224

Liu, X., Gurel, V., Morris, D., Murray, D. W., Zhitkovich, A., Kane, A. B., et al. (2007). Bioavailability of nickel in single-wall carbon nanotubes. Adv. Mater. 19, 2790-2796. doi: 10.1002/adma.200602696

Lynch, I., Weiss, C., and Valsami-Jones, E. (2014). A strategy for grouping of nanomaterials based on key physico-chemical descriptors as a basis for saferby-design NMs. Nano Today 9, 266-270. doi: 10.1016/j.nantod.2014.05.001

Ma, X., and Wang, C. (2010). Fullerene nanoparticles affect the fate and uptake of trichloroethylene in phytoremediation systems. Environ. Eng. Sci. 27, 989-992. doi: 10.1089/ees.2010.0141

Mauter, M. S., and Elimelech, M. (2008). Environmental applications of carbon-based nanomaterials. Environ. Sci. Technol. 42, 5843-5859. doi: $10.1021 /$ es8006904

Mondal, A., Basu, R., Das, S., and Nandy, P. (2011). Beneficial role of carbon nanotubes on mustard plant growth: an agricultural prospect. J. Nanopart. Res. 13, 4519-4528. doi: 10.1007/s11051-011-0406-z

Mueller, N. C., Buha, J., Wang, J., Ulrich, A., and Nowack, B. (2013). Modeling the flows of engineered nanomaterials during waste handling. Environ. Sci. 15, 251-259. doi: 10.1039/C2EM30761H

Mukherjee, A., Peralta-Videa, J. R., Bandyopadhyay, S., Rico, C. M., Zhao, L., and Gardea-Torresdey, J. L. (2014a). Physiological effects of nanoparticulate $\mathrm{ZnO}$ in green peas (Pisum sativum L.) cultivated in soil. Metallomics 6, 132-138. doi: $10.1039 / \mathrm{c} 3 \mathrm{mt} 00064 \mathrm{~h}$

Mukherjee, A., Pokhrel, S., Bandyopadhyay, S., Mädler, L., Peralta-Videa, J. R., and Gardea-Torresdey, J. L. (2014b). A soil mediated phyto-toxicological study of iron doped zinc oxide nanoparticles (Fe@ZnO) in green peas (Pisum sativum L.). Chem. Eng. J. 258, 394-401. doi: 10.1016/j.cej.2014.0 6.112

Ng, T. B., Chan, W. Y., and Yeung, H. W. (1992). Proteins with abortifacient, ribosome inactivating, immunomodulatory, antitumor and anti-AIDS activities from Cucurbitaceae plants. Gen. Pharmacol. 23, 575-590. doi: 10.1016/03063623(92)90131-3

Nowack, B., David, R. M., Fissan, H., Morris, H., Shatkin, J. A., Stintz, M., et al. (2013). Potential release scenarios for carbon nanotubes used in composites. Environ. Int. 59, 1-11. doi: 10.1016/j.envint.2013.04.003

Nyberg, L., Turco, R. F., and Nies, L. (2008). Assessing the impact of nanomaterials on anaerobic microbial communities. Environ. Sci. Technol. 42, 1938-1943. doi: $10.1021 /$ es072018g

Ogura, I., Kotake, M., Hashimoto, N., Gotoh, K., and Kishimoto, A. (2013). Release characteristics of single-wall carbon nanotubes during manufacturing and handling. J. Phys. 429, 012057.

Petersen, E. J., Henry, T. B., Zhao, J., Maccuspie, R. I., Kirschling, T. L., Dobrovolskaia, M. A., et al. (2014). Identification and avoidance of potential artifacts and misinterpretations in nanomaterial ecotoxicity measurements. Environ. Sci. Technol. 48, 4226-4246. doi: 10.1021/es4052999

Petersen, E. J., Pinto, R. A., Landrum, P. F., and Weber, J. W. Jr. (2009). Influence of carbon nanotubes on pyrene bioaccumulation from contaminated soils by earthworms. Environ. Sci. Technol. 43, 4181-4187. doi: 10.1021/es80 3023a

Petersen, E. J., Zhang, L., Mattison, N. T., O'carroll, D. M., Whelton, A. J., Uddin, N., et al. (2011). Potential release pathways, environmental fate, and ecological risks of carbon nanotubes. Environ. Sci. Technol. 45, 9837-9856. doi: $10.1021 /$ es201579y

Raman, A., and Lau, C. (1996). Anti-diabetic properties and phytochemistry of Momordica charantia L. (Cucurbitaceae). Phytomedicine 2, 349-362. doi: 10.1016/S0944-7113(96)80080-8

Rasool, K., and Lee, D. S. (2015). Influence of multi-walled carbon nanotubes on anaerobic biological sulfate reduction processes. J. Nanoelectronics Optoelectronics 10, 485-489. doi: 10.1166/jno.2015.1787

Rodrigues, D. F., Jaisi, D. P., and Elimelech, M. (2013). Toxicity of functionalized single-walled carbon nanotubes on soil microbial communities: implications for nutrient cycling in soil. Environ. Sci. Technol. 47, 625-633. doi: $10.1021 /$ es304002q 
Ruan, G., Sun, Z., Peng, Z., and Tour, J. M. (2011). Growth of Graphene from Food, Insects, and Waste. ACS Nano 5, 7601-7607. doi: 10.1021/nn202625c

Samaj, J., Baluska, F., Voigt, B., Schlicht, M., Volkmann, D., and Menzel, D. (2004). Endocytosis, actin cytoskeleton, and signaling. Plant Physiol. 135, 1150-1161. doi: 10.1104/pp.104.040683

Saxena, M., Maity, S., and Sarkar, S. (2014). Carbon nanoparticles in 'biochar' boost wheat (Triticum aestivum) plant growth. RSC Adv. 4:39948. doi: 10.1039/c4ra06535b

Serag, M. F., Kaji, N., Tokeshi, M., and Baba, Y. (2015). "Carbon nanotubes and modern nanoagriculture," in Nanotechnology and Plant Sciences, eds H. Manzer, H. Mohamed, and M. Firoz (Berlin: Springer International Publishing), 183-201.

Servin, A., Elmer, W., Mukherjee, A., De La Torre-Roche, R., Hamdi, H., White, J. C., et al. (2015). A review of the use of engineered nanomaterials to suppress plant disease and enhance crop yield. J. Nanopart. Res. 17:92. doi: 10.1007/s11051-015-2907-7

Sharon, M., and Sharon, M. (2010). Carbon Nano Forms and Applications. New York, NY: McGraw Hill Professional.

Shrestha, B., Acosta-Martinez, V., Cox, S. B., Green, M. J., Li, S., and Canas-Carrell, J. E. (2013). An evaluation of the impact of multiwalled carbon nanotubes on soil microbial community structure and functioning. J. Hazard. Mater. 261, 188-197. doi: 10.1016/j.jhazmat.2013.07.031

Simonet, B. M., and Valcarcel, M. (2009). Monitoring nanoparticles in the environment. Anal. Bioanal. Chem. 393, 17-21. doi: 10.1007/s00216-0082484-z

Sonkar, S. K., Roy, M., Babar, D. G., and Sarkar, S. (2012). Water soluble carbon nano-onions from wood wool as growth promoters for gram plants. Nanoscale 4:7670. doi: $10.1039 / \mathrm{c} 2 \mathrm{nr} 32408 \mathrm{c}$

Srivastava, V., Gusain, D., and Sharma, Y. C. (2015). Critical review on the toxicity of some widely used engineered nanoparticles. Ind. Eng. Chem. Res. 54, 6209-6233. doi: 10.1021/acs.iecr.5b01610

Stampoulis, D., Sinha, S. K., and White, J. C. (2009). Assay-dependent phytotoxicity of nanoparticles to plants. Environ. Sci. Technol. 43, 9473-9479. doi: $10.1021 /$ es 901695 c

Sun, T. Y., Gottschalk, F., Hungerbühler, K., and Nowack, B. (2014). Comprehensive probabilistic modelling of environmental emissions of engineered nanomaterials. Environ. Pollut. 185, 69-76. doi: 10.1016/j.envpol.2013.10.004

Tiwari, D. K., Dasgupta-Schubert, N., Villaseñor Cendejas, L. M., Villegas, J., Carreto Montoya, L., and Borjas García, S. E. (2013). Interfacing carbon nanotubes (CNT) with plants: enhancement of growth, water and ionic nutrient uptake in maize (Zea mays) and implications for nanoagriculture. Appl. Nanosci. 4, 577-591. doi: 10.1007/s13204-013-0236-7

Tong, Z., Bischoff, M., Nies, L., Applegate, B., and Turco, R. F. (2007). Impact of fullerene (C60) on a soil microbial community. Environ. Sci. Technol. 41, 2985-2991. doi: 10.1021/es0619531

Tong, Z., Bischoff, M., Nies, L. F., Myer, P., Applegate, B., and Turco, R. F. (2012). Response of soil microorganisms to as-produced and functionalized singlewall carbon nanotubes (SWNTs). Environ. Sci. Technol. 46, 13471-13479. doi: $10.1021 /$ es303251r

Tripathi, S., and Sarkar, S. (2014). Influence of water soluble carbon dots on the growth of wheat plant. Appl. Nanosci. 5, 609-616. doi: 10.1007/s13204-0140355-9
Tripathi, S., Sonkar, S. K., and Sarkar, S. (2011). Growth stimulation of gram (Cicer arietinum) plant by water soluble carbon nanotubes. Nanoscale 3, 1176-1181. doi: $10.1039 / \mathrm{c} 0 \mathrm{nr} 00722 \mathrm{f}$

Wang, D., Wang, G., Zhang, G., Xu, X., and Yang, F. (2013). Using graphene oxide to enhance the activity of anammox bacteria for nitrogen removal. Bioresour. Technol. 131, 527-530. doi: 10.1016/j.biortech.2013. 01.099

Wang, X., Han, H., Liu, X., Gu, X., Chen, K., and Lu, D. (2012). Multi-walled carbon nanotubes can enhance root elongation of wheat (Triticum aestivum) plants. J. Nanopart. Res. 14:841. doi: 10.1007/s11051-0120841-5

Wild, E., and Jones, K. C. (2009). Novel method for the direct visualization of in vivo nanomaterials and chemical interactions in plants. Environ. Sci. Technol. 43, 5290-5294. doi: 10.1021/es900065h

$\mathrm{Xu}$, J., Tomimoto, H., and Nakayama, T. (2011). What is inside carbon nanohorn aggregates? Carbon 49, 2074-2078. doi: 10.1016/j.carbon.2011.0 1.042

Yang, W., Ratinac, K. R., Ringer, S. P., Thordarson, P., Gooding, J. J., and Braet, F. (2010). Carbon nanomaterials in biosensors: should you use nanotubes or graphene? Angew. Chem. Int. Ed. 49, 2114-2138. doi: 10.1002/anie.2009 03463

Zhang, L., Petersen, E. J., Zhang, W., Chen, Y., Cabrera, M., and Huang, Q. (2012). Interactions of 14C-labeled multi-walled carbon nanotubes with soil minerals in water. Environ. Pollut. 166, 75-81. doi: 10.1016/j.envpol.2012. 03.008

Zhang, M., Gao, B., Chen, J., and Li, Y. (2015). Effects of graphene on seed germination and seedling growth. J. Nanopart. Res. 17:78. doi: 10.1007/s11051015-2885-9

Zhao, L., Hernandez-Viezcas, J. A., Peralta-Videa, J. R., Bandyopadhyay, S., Peng, B., Munoz, B., et al. (2013). ZnO nanoparticle fate in soil and zinc bioaccumulation in corn plants (Zea mays) influenced by alginate. Environ. Sci. 15, 260-266. doi: 10.1039/c2em3 $0610 \mathrm{~g}$

Zhao, L., Peralta-Videa, J. R., Peng, B., Bandyopadhyay, S., Corral-Diaz, B., OsunaAvila, P., et al. (2014). ). Alginate modifies the physiological impact of $\mathrm{CeO}_{2}$ nanoparticles in corn seedlings cultivated in soil. J. Environ. Sci. 26, 382-389. doi: 10.1016/S1001-0742(13)60559-8

Zheng, X., Su, Y., Chen, Y., Wan, R., Li, M., Wei, Y., et al. (2014). Carboxyl-modified single-walled carbon nanotubes negatively affect bacterial growth and denitrification activity. Sci. Rep. 4:5653. doi: 10.1038/srep0 5653

Conflict of Interest Statement: The authors declare that the research was conducted in the absence of any commercial or financial relationships that could be construed as a potential conflict of interest.

Copyright (c) 2016 Mukherjee, Majumdar, Servin, Pagano, Dhankher and White. This is an open-access article distributed under the terms of the Creative Commons Attribution License (CC BY). The use, distribution or reproduction in other forums is permitted, provided the original author(s) or licensor are credited and that the original publication in this journal is cited, in accordance with accepted academic practice. No use, distribution or reproduction is permitted which does not comply with these terms. 